\title{
Shellfish and Residual Chemical Contaminants: Hazards, Monitoring, and Health Risk Assessment Along French Coasts
}

\author{
Marielle Guéguen ${ }^{1}$, Jean-Claude Amiard ${ }^{2}$ Nathalie Arnich ${ }^{3}$ Pierre-Marie Badot ${ }^{4}$, Didier Claisse ${ }^{5}$, \\ Thierry Guérin ${ }^{6}$ and Jean -Paul Vernoux ${ }^{1, *}$
}

\footnotetext{
${ }^{1}$ Unité des microorganismes d'intérêt laitier et alimentaire EA 3213, UFR ICORE 146 - Université de Caen-Basse Normandie, Esplanade de la Paix, 14032 Caen Cedex5 - France

${ }^{2}$ Service d'Ecotoxicologie - "Mer, Molécules, Santé", EA 2160 - Université de Nantes - France

${ }^{3}$ Direction Santé Alimentation - Agence nationale de sécurité sanitaire de l'alimentation, de l'environnement et du travail (ANSES), 27-31 avenue du Général Leclerc, 94701 Maisons-Alfort - France

4 UMR Chrono-environnement, CNRS/Université de Franche-Comté usc INRA - F-25030 Besançon cedexFrance

${ }^{5}$ Département Biogéochimie et Ecotoxicologie - ROCCH - IFREMER, Rue de l'ile d'Yeu - BP 21105 - 44311 Nantes Cedex 3 - France

${ }^{6}$ Unité Contaminants inorganiques et minéraux de l'environnement (CIME) - Agence nationale de sécurité sanitaire de l'alimentation, de l'environnement et du travail (ANSES) - Laboratoire de sécurité des aliments, ANSES - LSA - CIME 23, Avenue du Général de Gaulle, 94706 Maisons-Alfort Cedex - France
}

*: Corresponding author : Jean-Paul Vernoux, email address : jean-paul.vernoux@unicaen.fr

\begin{abstract}
:
Shellfish farming is a common industry along European coasts. According to the 2005-2006 data from the French National Shellfish Farming Committee (CNC - Comité National de la Conchyliculture 2010; see Table 1 for a list of acronyms and abbreviations used in this chapter), Spain is the largest shellfish producer in Europe ( $270,000 \mathrm{t}$ ) and France ranks second, producing 200,000 t of shellfish annually. France is the leading European oyster producer, with an annual output of 130,000 t of Crassostrea gigas, and ranks fourth in the world after China, Japan, and Korea. The top three European mussel (Mytilus edulis and Mytilus galloprovincialis) producers are Spain (260,000 t), Denmark (80,000 t), and France $(65,000 \mathrm{t})$. For other shellfish, the French annual output level is $15,000 \mathrm{t}$ for king scallops (Pecten maximus) and a few thousand tons for Ruditapes clams (Ruditapes decussatus and Ruditapes philippinarum) and cockles (Cerastoderma edule). The economic impact of shellfish farming is considerable; despite fairly long production lead times and difficult operating conditions, shellfish farming generates annual sales of more than 650 million Euros in France, owing to its high added value.
\end{abstract}




\section{Introduction}

Shellfish farming is a common industry along European coasts. According to the 2005-2006 data from the French National Shellfish Farming Committee (CNC - Comité National de la Conchyliculture 2010; see Table 1 for a list acronyms and abbreviations used in this article), Spain is the largest shellfish producer in Europe $(\sim 270,000 \mathrm{t})$ and France ranks second, producing $200,000 \mathrm{t}$ of shellfish annually. France is the leading European oyster producer, with an annual output of 130,000 t of Crassostrea gigas, and ranks fourth in the world after China, Japan and Korea. The top three European mussel (Mytilus edulis and $M$. galloprovincialis) producers are Spain $(260,000 \mathrm{t})$, Denmark $(80,000 \mathrm{t})$ and France $(65,000 \mathrm{t})$. For other shellfish, the French annual output level is $15,000 \mathrm{t}$ for king scallops (Pecten maximus) and a few thousand t for Ruditapes clams ( $R$. decussatus and $R$. philippinarum), and cockles (Cerastoderma edule). The economic impact of shellfish farming is considerable; despite fairly long production lead times and difficult operating conditions, shellfish farming generates annual sales of more than 650 million Euros in France, owing to its high added value.

The main species of shellfish consumed in France are the Pacific oyster (C. gigas), mussels ( $M$. edulis and $M$. galloprovincialis), king scallop ( $P$. maximus), winkle (Littorina littorea), whelk (Buccinum undatum), cockle, Ruditapes clams and scallops (Pecten spp., Chlamys spp.).

Current European regulations focus on regulating microbiological agents, phycotoxins and some chemical contaminants. Since 2006, these regulations have been compiled under the name of the 'Hygiene Package'. Because of increasing concern for the presence of contaminants in the marine environment, the French Food Safety Agency (AFSSA; now named the French Agency for Food, Environmental and Occupational Health \& Safety, ANSES) issued a report in 2008 on the monitoring of chemicals in shellfish farming areas, and on health risks associated with shellfish consumption (AFSSA 2008b).

The purpose of this review is to address the residual chemical hazards that exist in shellfish that are routinely sampled from the natural marine environment and from the market place. We have included data on exposure levels and body burdens of many contaminants, and have related these data to human health risks. We have also addressed the concentration of contaminants found in the context of current regulatory and food safety standards. The data compiled here are designed to provide readers with a basis for assessing whether or not it is necessary to continue, or even extend environmental chemical contaminant monitoring to other chemicals that pose significant potential consumer health risks.

\section{Regulation of Shellfish Food Safety in Europe}

Food safety monitoring of shellfish farming areas falls under European regulatory jurisdiction and is defined in the "Hygiene Package", which came into force on 1 January 2006. There are several specific sections of this regulation that apply to live bivalve molluscs. Two of these regulations (EC 2004a,b) are directed toward industry professionals ( $N^{\circ} 852 / 2004$ and $\mathrm{N}^{\circ} 853 / 2004$ ), and two others (EC 2004c; EC 2006b) apply to competent authorities having to do with official controls ( $N^{\circ} 854 / 2004$ and $N^{\circ} 882 / 2006$ ). Directive (EEC) $N^{\circ} 492 / 91$ (EEC 1991), which had previously set the hygiene rules for the production and marketing of live bivalve molluscs, was repealed. A general presentation of these regulations is presented below, and deals only with the sections on residual chemical contaminants. 


\subsection{Provisions of the Hygiene Package}

Regulation (EC) 852/2004 (EC 2004b) lays down general rules on food hygiene, and applies to primary production (farm and fishery products). It is complemented by Regulation (EC) 853/2004 (EC 2004a), which lays down additional specific hygiene rules for products of animal origin. Annex III, Section VII of Regulation (EC) 853/2004 specifies the requirements for live bivalve molluscs. Regulations (EC) 854/2004 and 882/2006 ( EC 2004c ; EC 2006b) apply to official control bodies, and define a legal framework for setting the locations and boundaries of production, and relaying areas (depurating areas). The regulations also require food safety monitoring, by sampling, to screen for chemical and microbiological contaminants.

A clear distinction must be made between primary production of shellfish and the other operations that are required to bring shellfish to the market, because the regulatory obligations are different. Primary shellfish production concerns all operations carried out before shellfish reach an approved purification establishment: rearing, harvesting and transport of the produce. Annex I of Regulation (EC) 852/2004, and some provisions in Annex III, Section VII of Regulation (EC) 853/2004 apply to primary producers. Producers must be registered, but are under no obligation to set up Hazard Analysis Critical Control Point (HACCP) procedures. The activities of the purification and dispatch establishments (finishing, packing, etc.) are not regarded to constitute primary production. The provisions of Annex II of Regulation (EC) 852/2004 and of Annex III, Section VII of Regulation (EC) $853 / 2004$ apply to these establishments. These establishments must be approved by the competent authority, and are under an obligation to introduce HACCP procedures.

The classification of production into Class A, B and C areas is based solely on measures having to do with microbiological contamination; these measures are defined by the Hygiene Package, and Regulations 853/2004 and 854/2004, in particular:

- Class A areas are those from which live bivalve molluscs may be harvested for direct human consumption;

- Class B areas are those from which live bivalve molluscs approach conformity, but before being marketed for human consumption require a short, but sufficient purifying treatment;

- Class $C$ areas are those from which live bivalve molluscs can be harvested only after relaying (depurating) for a long period, with purification, or after intensive purification by an appropriate method.

At the EC level, the Hygiene Package regulates the monitoring of production areas during operations (854/2004, Annex II, Chapter II.b) for three types of hazards: microbiological, phytoplanktonic/phycotoxic and chemical. Thus, although under the Hygiene Package there is no obligation to test for chemical contaminants for the purposes of classifying the production areas; however, there is an obligation to chemically monitor these areas.

\subsection{Provisions on Chemical Contaminants}

To be regarded as edible bivalve molluscs must also comply with maximum levels of certain contaminants defined in Regulation (EC) 1881/2006 of 19 December 2006 (EC 2006c), which replaces Regulation (EC) 466/2001 (EC 2001), as amended by Regulation (EC) $629 / 2008$ of 2 July 2008 (EC 2008a). These contaminant thresholds (Table 2) apply to the edible parts of bivalve molluscs, i.e., the whole flesh, except for the king scallop, for which the digestive gland is not taken into account (Article 1 of Regulation (EC) 1881/2006). Non- 
bivalve molluscs (gastropods), echinoderms and tunicates are not covered by the European regulations, but in France, in a recommendation issued on 31 October 2007 (AFSSA 2007b), AFSSA considers that the cadmium threshold set by decree on 21 May 1999 is appropriate: $2 \mathrm{mg} \mathrm{kg}^{-1}$ fresh mass for whelks (gastropod, B. undulum) (JORF 1999). For echinoderms and tunicates, given their particularly low levels of consumption, it is not regarded as necessary to set a regulatory threshold, but rather a guideline value of $2 \mathrm{mg} \mathrm{kg}^{-1}$ fresh mass (AFSSA 2007b).

\section{Identifying Residual Chemical Hazards in the Marine Environment and in Shellfish}

To identify the risks of chemical residues in the marine environment being transferred to bivalve molluscs, and thence to humans, it is necessary to target, among the many potentially toxic chemicals, those that have a likelihood of being released by human activities in the vicinity of shellfish farming areas. That does not mean that contamination of the environment and of the bivalve molluscs by the chemicals addressed in this paper has always been demonstrated. Hazard identification is usually conducted independently of the likelihood of an accident occurring. Consequently, hazard identification does not include chemicals that may be released into the environment from hitherto unidentified sources or following accidental spills, irresponsibility or acts of malice.

The main sources of contaminants are of human origin (Manta et al. 2002). They involve the following: terrestrial and marine crop and livestock farming; human habitation (energy production, building and demolition, wastewater, incineration of household waste, heating, etc.); land transport (infrastructures, vehicles); energy production; industry (solid waste, liquid effluents and gas emissions, end-of-life of products, etc.); maritime transport and related activities (port activities, dredging, etc.), as well as some leisure activities (golf courses, water sports, sailing, etc.). Pharmaceutical residues have been found in environmental waters and in the marine environment, so they also could qualify as pollutants (Walraven and Laane 2009; Fatta-Kassinos et al. 2011).

Crop and livestock farming activities results in the release of organic matter and nutrients (nitrates, phosphates, potassium) into the environment; these can contribute to the eutrophication of the marine environment and cause major changes to aquatic community dynamics. Many chemicals are, or have been used in farming: plant protection products, biocides, veterinary drugs (including antibiotics), any of which may contaminate the marine environment at some time (Schaffner et al. 2009). Human habitations can also be major sources of organic matter release into aquatic environments, particularly in coastal areas, via wastewater release (Heinzow et al. 2007; Schaffner et al. 2009). Incinerators and domestic heating equipment release persistent organic pollutants (POPs), such as dioxins, PCBs, PAHs, etc. (Lewtas 2007; Van Caneghem et al. 2010). Industrial activities also release a very wide range of toxic chemicals. Transport and energy production release such substances as PAHs, trace elements, radionuclides and many atmospheric pollutants (England et al. 2001). Through their toxic potential, these substances can cause direct adverse effects on the marine environment, on farmed molluscs and indirect effects on human consumers. 


\subsection{Inorganic Contaminants}

Metals (trace elements) are naturally present in many rocks and minerals. Due to natural weathering of the earth's crust, they are found in all environmental compartments, including seawater. Some trace elements that are absorbed by living organisms accumulate in the food chain, and therefore present a risk to humans, who are the final consumers at the top of the food chain (Hamilton 2004 ; Hillwalker et al. 2006). Shellfish filter large amounts of water to extract their food, and are excellent bioaccumulators (Claisse 1989). Any contaminants in the water, from natural sources or pollution, are easily concentrated in shellfish flesh, particularly metals, such as the following: mercury, cadmium, lead, copper and zinc. Metals are mainly fixed in particular organs, such as the digestive gland (Soto et al. 1996), which plays a part in assimilation, excretion and detoxification (Johnson et al. 1996). These organs are generally the parts of the organisms that are eaten by humans (except for king scallops whose flesh is consumed only in France).

In Tables 3 and 4, we summarize the main metal contaminants found in the environment, their human-activity sources and we categorize their toxicity and risk levels. Levels of contamination in marketed shellfish are given by species for the three regulated metal contaminants (lead, cadmium and mercury); the results come from the CALIPSO (2005) and first Total Diet Study (EAT 2004) which were performed in France (Table 3). The levels reported in these tables can be compared with the maximum permitted levels set for fishery products. For example, cadmium levels are above the maximum permitted limits in some scallop species (1.14 $\mathrm{mg} \mathrm{kg}^{-1}$ fresh wt), while the other bivalve molluscs show lower levels no more than $0.040 \mathrm{mg} \mathrm{kg}^{-1}$ fresh wt. For lead and mercury, none of the species sampled were above the maximum permitted levels (lead $<0.26 \mathrm{mg} \mathrm{kg}^{-1}$ fresh wt, and mercury < $0.003 \mathrm{mg} \mathrm{kg}^{-1}$ fresh wt). The observed values in French shellfish farming areas (Fig. 1A, B, C and $\mathrm{E}$ ) are very close to those observed in marketed shellfish just before consumption.

Table 3 also shows that molluscs have high concentrations of arsenic, the highest levels being found in whelks (15.8 $\mathrm{mg} \mathrm{kg}^{-1}$ fresh wt). However, contamination levels in shellfish are lower than those in crustaceans, fish and other seafood; the highest levels were found in octopus (42 mg kg-1 fresh wt: Leblanc et al. 2006; Sirot et al. 2009). In 1988, the mean arsenic levels in bivalve molluscs (mussels and oysters) along the French coast ranged from 10 to $30 \mathrm{mg} \mathrm{kg}^{-1}$ (Michel 1993); arsenic residues were the most frequently encountered, irrespective of geographical area and species. It is difficult to link the highest levels with possible pollution sources. For example, organisms in the major estuaries (Seine, Loire and Gironde rivers) are less contaminated than those in adjacent coastal areas. It seems that the levels of arsenic in the environment derive less from bioaccumulation than from whether the metal is in organic or inorganic form (Michel 1993). In laboratory experiments, the oyster $C$. virginica bioaccumulates little inorganic arsenic and only a fraction of the organic arsenic present in the phytoplankton (Sanders et al. 1989). The arsenic fixed on inert particles of seston is poorly bioconcentrated in the oyster C. gigas (Ettajani et al. 1996), but the small amount that passes through the oyster causes intense erosion of the mitochondrial cristae, leading eventually to cellular respiratory failure. In the peppery furrow shell (or sand gaper) Scrobicularia plana, bioconcentrated arsenic levels match the levels of sediment contamination (Langston 1983). In the winkle, arsenic levels vary from 9 to $70 \mathrm{mg} \mathrm{kg}^{-1} \mathrm{dry}$ wt, their exact level depending on the degree of contamination of their food sources (Fucus spp.), and the environment (Bryan et al. 1976, 1983). Among other unregulated metals, zinc and magnesium levels are higher in oysters than in mussels (Table 4).

Polonium $\left(\mathrm{Po}^{210}\right)$ is one of the radionuclides that may have a health impact (exposure threshold 2 millisieverts (mSv) $\mathrm{yr}^{-1}$; Table 5). Exposure by ingestion is significant, and annual intake can reach hundreds of $\mu$ Sv per year in adults (Pradel et al. 2001). 


\subsection{Organic Contaminants}

Bivalve molluscs are exposed to a multitude of persistent or non-persistent organic contaminants belonging to very different chemical families. Tables 6 and 7 give a summary description of the main data available in the literature on pollutants identified in water, sediments and in bivalve molluscs (Leblanc et al. 2006; OSPAR 2008) and include information on toxicity and risk category.

In regard to regulated organic contaminants (Table 6), PCBs and dioxins (PCDD/Fs) are found at levels far below the regulatory thresholds $\left(8 \mathrm{pg} \mathrm{g}^{-1}\right.$ of dl-PCBs + dioxins) in oysters $\left(<0.6 \mathrm{pg} \mathrm{g}^{-1}\right)$, mussels $\left(<0.6 \mathrm{pg} \mathrm{g}^{-1}\right)$ and king scallops $\left(<0.4 \mathrm{pg} \mathrm{g}^{-1}\right)$. The benzo[a]pyrene sanitary threshold is neither exceeded in marketed mussels (Table 6), nor in those that are farm-sourced (Fig. 1D and E). Some data on contamination of shellfish flesh are also available for unregulated organic contaminants (Table 7). Of about one hundred existing organostannic compounds, mono-, di- and tri-butyltin (MBT, DBT and TBT) and mono-, diand tri-phenyl tin (MPT, DPT and TPT) are the most frequently found in fishery products. Octyltins are not detected in fishery products. Based on available data, results of two recent studies were that exposure to organotins through seafood does not seem to present a risk for the adult consumer (AFSSA 2006 ; Guérin et al. 2007). There are other relevant contaminating organic compounds, but very few data are available for them:

- $\quad$ synthetic musks, nitro-musks and polycyclic musks from the perfume industry;

- octylphenol ethoxylates (OPEs) and nonylphenol ethoxylates (NPEs), from industrial cleaning, maintenance of public places and processing of leather and textiles;

- hydrocarbons, particularly toluene, ethyl benzene, xylene (BTEX) and phenols, from the offshore oil industry via sludge and drill cuttings, process water and accidental spills or illegal discharges;

- substances on the list of 33 priority substances in Annex $X$ of Directive (EC) $N^{\circ} 105 / 2008$ (EC 2008b), especially alachlorine, chloroalkanes, chlorfenvinphos, chlorpyrifos, di(2-ethylhexyl)phthalate (DEHP), diuron, endosulfan, hexachlorobutadiene, isoproturon, pentachlorobenzene, pentachlorophenol, trichlorobenzene and trifluralin;

- emerging contaminants including pharmaceuticals, hormones and endocrine disrupting compounds also present in aqueous environment (Richardson and Ternes 2005).

\subsection{Accumulation of Contaminants in Molluscs and Factors of Variation}

Shellfish are filter feeders that concentrate contaminants, and also have the ability to detoxify themselves. The balance between these two processes is not fixed but depends on many factors.

Contamination may be direct (from water), or via food ingestion. Food contamination in filterfeeding molluscs occurs via seston (suspended particulate matter, inert or living). As with inert particles, phytoplankton becomes contaminated by adsorbing chemical compounds onto their cell surfaces; sometimes, these chemicals are absorbed by diffusion into the cells. Food contamination (phytoplankton) generally leads to longer half-lives than does direct water contamination. The longer the duration of contact, the higher the level of contamination and the longer decontamination takes. The ration of organic to inorganic contaminants influences their distribution in organisms and their elimination rate. 


\subsubsection{Bioconcentration Factors (BCF)}

The concentration factor (CF) or bioconcentration factor (BCF) is a concept that was introduced by Polikarpov (1960). It is based on a relatively simple concept that a relationship exists between the concentration of a substance in an organism and the concentration of the same substance in the surrounding water. However, CFs are not easy to estimate; to do so, the two concentrations must remain constant. It is difficult to experimentally maintain constant concentrations in water for long periods of time, and in situ water concentrations fluctuate widely. No method for standardizing the estimation of CFs has been proposed. Numerous studies have been carried out to address this problem (Chong and Wang 2001 ; James et al. 2006 ; Miramand et al. 1980 ; Murray et al. 1991 ; Pruell et al. 1986). CF data for various organic pollutants have been recorded by different agencies (e.g., the International Atomic Energy Agency (IAEA) and the Groupe Radioécologique Nord-Cotentin) and have been published (Amiard-Triquet and Amiard 1980). CF values vary widely among different animal types and the resultant bioaccumulation values are influenced by many abiotic and biotic factors.

The best estimations of CFs are those that are determined in experiments that are performed in situ over long periods of time. Since the Water Framework Directive (WFD), Directive (EC) $N^{\circ} 60 / 2000$ (EC 2000) has come into force, water authorities are obliged to assess concentrations of pollutants in total seawater, dissolved concentrations and amounts in particulates. However, hydrophobic pollutants are essentially adsorbed onto particulates and their concentration is dependent on the concentration of these particulates in water. Such particulate concentrations fluctuate widely in space and time, so direct measurements in water were abandoned more than 20 years ago, under the French National Monitoring Network (RNO - Réseau national d'observation) and the OSPAR convention. The French Research Institute for Exploitation of the Sea (IFREMER - Institut français de recherche pour l'exploitation de la mer) considers that, at least for non-hydrophilic substances, the most effective monitoring target for contaminants are media that concentrate these substances: sediments and/or biota and particularly mussels and oysters, the two usual sentinel species. However, to meet the requirements of the WFD, the levels measured in these media must be converted into water concentrations. The tissue concentration in the molluscs is equal to the concentration in the water multiplied by the BCF. It is therefore possible to calculate the water concentrations, if the CF is known. James et al. (2006) provided BCFs for most substances that the EU considers to be priority ones (Table 8).

\subsubsection{Seasonal Fluctuations in Contaminant Concentrations}

Concentrations of chemical contaminants in bivalve molluscs fluctuate according to the time of year. This was noticed from the start of the RNO monitoring program in the early 1980s (Claisse 1992). The pattern for inorganic compounds is 'biological dilution', when bivalves reach sexual maturity; this occurs when the amount of contaminants remain the same, but the organism's body mass increases, and thus metal concentrations fall. This has been observed for cadmium, copper, lead and zinc in mussels (Amiard et al. 1986) and oysters (Amiard and Berthet 1996). The highest concentrations are recorded in winter and spring and the lowest in summer and autumn, with ratios of up to 1:4 depending on the contaminant and the species (Devier et al. 2005). The reverse pattern is found with lipophilic organic compounds, such as DDT in the oyster C. virginica; concentrations increase at sexual maturity, when oysters produce lipid-rich gametes (Butler 1973). Oysters also eliminate these 
pollutants through spawning (release of eggs into the water). With $C$. virginica, the risk to humans is therefore greatest at the moment of sexual maturity.

Because contaminants are only monitored annually, and because of the kinetic behavior of contaminants in molluscs, tracing individual contamination events over short periods of time is not possible. Therefore, the established programs are effective for monitoring chronic contamination, but not for short duration events; such events may thus go unnoticed between any two samplings of the sentinel species. However, alarms may be sounded from accidental discharges as a result of triggering increased mortality at sensitive developmental stages.

\subsubsection{Detoxification Mechanisms}

\section{Detoxification of Trace Elements}

Invertebrates exposed to toxic trace elements respond with two types of detoxification mechanisms (Amiard 1991). The first response is to render the metal insoluble by immobilizing it in the form of a salt. This occurs with silver sulphide in oysters, for example (Martoja et al. 1988). The second response is to induce metallothioneins (MTs), which are capable of detoxifying various trace elements (Amiard et al. 2006). MTs form complexes with the trace elements and render them harmless. Metallothioneins are stored in lysosomes and their concentration is proportional to that of toxic trace elements in the environment, as shown by an experiment with transplanted mussels in the western Mediterranean Sea (Mourgaud et al. 2002). Detoxification mechanisms in invertebrates vary widely from one species to another. In various oyster species, mobile cells called amoebocytes accumulate complexed metal from the blood. In Ostrea edulis, some amoebocytes accumulate copper, others zinc, or copper and zinc simultaneously. Other oyster species, such as $O$. angasi and C. gigas, only have one amoebocyte type, which accumulates copper and zinc equally well (George et al. 1984). Some species of molluscs (e.g., oysters and mussels) are capable of regulating the internal concentration (homeostasis) (within certain concentration limits) of certain essential trace elements, such as copper and zinc (Amiard et al. 1987).

The particular physical-chemical form of inorganic contaminants that are stored have consequences for the subsequent transfer of trace elements within trophic networks. The two above-mentioned detoxification processes (insolubilization and metallothionein induction) are very efficient, and species that use them can live in heavily contaminated environments. Such species may accumulate high levels of contaminants in some of their tissues. When these species are consumed, the metal-metallothionein complexes are ingested and digested, releasing the metals into the consumer's body in a manner that favors the assimilation of the metals. Therefore, the levels transferred to and absorbed by the consumer may be high. In contrast, when detoxification occurs by insolubilization, the resultant granules are poorly digested by the consumer or predator; hence, bioavailability is low.

\section{Detoxification of Organic Pollutants}

Some invertebrates are able to biotransform organic pollutants in special organs (e.g., the digestive gland) that render pollutants hydrosoluble, and therefore more easily eliminated (Narbonne and Michel 1997). This metabolic process occurs in two biotransformation stages: (1) phase I, oxidation and/or (2) phase II, conjugation. Phase I is controlled by P450 cytochromes or by flavin monooxygenases. In phase II, conjugation frequently takes place with glutathione and is catalyzed by glutathione S-transferase (GST). Occasionally, biotransformation activates a metabolite to a form that is more toxic than the parent 
molecule. A third detoxification pathway is possible, and involves the glycoprotein Pg170 (phase III). In phase III, organic pollutants are expelled from the cell. This protective elimination mechanism is efficient in molluscs (Bard 2000), and is known as multixenobiotic resistance (Pain and Parant 2003).

\section{The Effect of Shellfish Purification on Chemical Contaminants}

In the course of shellfish production, shellfish are purified to reduce the risk of microbiological contamination. The question is whether this microbiological purification helps reduce the amounts of any chemical contaminants also present in the shellfish.

Microbiological purification consists of immersing live shellfish in tanks continuously fed clean seawater for a period that is sufficient to eliminate microbiological contaminants and render the shellfish suitable for human consumption. The regulatory definition of "clean seawater" is found in point $h$ of Article 2 of Regulation (EC) 852/2004 (EC 2004b). This very vague definition sets goals, without clearly defining the criteria to be fulfilled. The French Directorate for Food (DGAL), therefore, commissioned AFSSA to establish seawater quality criteria suitable for handling fishery products. AFSSA delivered its opinion on 26 July 2007 (AFSSA 2007a). Microbiological purification is required only for shellfish from Class B and C production areas, and the produce from these areas can be harvested, but cannot be directly marketed. The time required for purification varies between two and several days, depending on the system used. In France, the duration for purification is 48 hours for Class B shellfish (industry recommendation). The duration of purification may be reduced for some fragile shellfish species (e.g., wedge shells and Ruditapes clams); the regulations do not impose a minimum duration.

When kept in large quantities of clean seawater, contaminated marine organisms purify themselves, eliminating the chemical contaminants that they have accumulated in their soft tissues. The measure used to track elimination rate is biological half-life, i.e., the time required for half the amount of a substance to disappear from the organism or organ.

The kinetics of decontamination depend not only on the difference in initial concentration, but also on the following factors (Casas and Bacher 2006) :

- chemical-specific factors- (type(s) of the contaminant(s), level(s) of contamination, variations in contamination over time, contamination pathways (i.e., water, food or inert particles));

- physiological factors of the organism (growth rate, mass variation over time, type of sexual state maturity, physiological status, differences between species, etc.);

- environmental factors (temperature, and food quantity and quality).

From the foregoing, it is obvious that the elimination kinetics, the mechanisms of elimination, and quantities of toxicants eliminated will be species-dependent. Mussels are capable of eliminating cellular organelles (lysosomes) that were involved in detoxifying various contaminants, whereas oysters retain their lysosomes for life (George et al. 1978). In some species, certain cumulative toxins continue to be accumulated throughout an animals' lifetime.

In Table 9 we provide examples of the chemical half-lives of several contaminants in bivalve molluscs. Although this table is far from exhaustive, it indicates the wide variations in half-life elimination times for various contaminants and species. 
The above information disclosed on elimination half lives of various chemicals indicates that the 48 hour immersion time, used to purify microbes from Class B shellfish, is far from sufficient to also remove chemical contaminants (organic and metal). In fact, considerably more research results are needed to achieve reliable estimates of the half-lives in shellfish species of the main contaminants found in the marine environment. These data would be extremely useful in estimating the dissipation times, and therefore the seriousness of accidental chemical pollution or spills. Of course, the key question after such events occur is how soon, and under what conditions marketing of exposed shellfish can be resumed. Despite the usefulness of such information, the current regulations do not require that the disposition of chemical contaminates be considered.

\section{Chemical Monitoring in the Environment and in Shellfish}

\subsection{Environmental Chemical Monitoring Programs}

Shellfish are at risk of from pollutants primarily because of their environmental exposure. To protect shellfish from chemical contamination, systems have been set established to periodically monitor waters of coastal areas for selected contaminants (Apeti et al. 2010 ; Cantillo 1998 ; Claisse 1989 ; Franco et al. 2002 ; O'Connor 1998). The goal of the OSPAR convention for the protection of the northeast Atlantic marine environment is to reduce pollution. The OSPAR Hazardous Substances Committee listed the substances to be monitored in order of priority, taking into account those that are already prioritized by other regulations, e.g., under the WFD. Under the Mediterranean Action Plan (MAP) of the United Nations Environment Programme (UNEP), the Barcelona Convention for the Protection of the Mediterranean Sea Against Pollution (MED POL) has implemented phase III of the MED POL monitoring program.

European Directive (EC) N¹05/2008 (EC 2008b), which amends Directive (EC) N60/2000 (EC 2000), and lays down the environmental quality standards for water, provides for updating the list of priority substances. The updates give the maximum allowable concentration of each substance (set up to avoid serious and irreversible consequences of acute short-term exposure for an ecosystem), as well as the allowable mean annual concentration (to avoid long-term irreversible consequences).

In France, the monitoring of water contamination along the French coast has been performed by the RNO, renamed ROCCH (Réseau d'Observation de la Contamination CHimique du milieu marin), in 2008. ROCCH was established by the French Ministry of the Environment in 1974 , and is coordinated by IFREMER. Its purpose is to assess levels and trends in chemical contamination along the coast. Until 2007, the RNO monitored only sediments and bivalve molluscs, in which contaminants are concentrated, to meet French obligations under the OSPAR and Barcelona conventions. In addition to sediments and bivalves, ROCCH also monitors the biological effects of contamination by organic forms of tin (which cause imposex; Huet et al 2003).

\subsubsection{Monitoring Contaminants: the RNO Program and its Successor (ROCCH)}

Because of the difficulty in obtaining valid samples suitable for water trace analysis, and the low spatial and temporal representativeness of such samples, RNO monitoring has focused on the matrices that absorb contaminants, i.e., biota and sediments. Therefore, bivalve 
molluscs (mussels and oysters) are used as quantitative contamination indicators (Claisse 1999).

The concepts of indicator- and sentinel-species are widely used in many countries, e.g., Mussel Watch in the USA (Cantillo 1998 ; Claisse 1989 ; Goldberg et al. 1983 ; O'Connor 1998 ; Sukasem and Tabucanon 1993 ; Tripp et al. 1992).

In France, testing for chemical contaminants was performed annually in November for all substances, and biannually (February and November) for trace elements (Table 10). The interpretation of the analytical results requires consideration of the differences among species in bioaccumulation; for example, the concentration ratios between oysters and mussels are approximately 50 for silver, 2.5 for cadmium, 10 for copper and 15 for zinc (Claisse et al. 2006).

The RNO results have also sometimes been used for monitoring food safety, together with results from official regulatory controls.

The main achievements of the RNO from 1979 to 2007 included the following:

- establishment of national baseline levels for nine trace elements, 14 organochlorine chemicals and 37 PAHs (Table 10);

- identification of reference or control sites for monitoring if

- natural contaminants are present at representative levels, or

- synthetic chemicals exist at levels that do not reflect significant inputs, and

- hotspots exist (particularly contaminated areas; e.g., the Gironde is a hotspot for cadmium, and the Seine for PCBs);

- determination of temporal trends for 33 contaminants;

- assembling a bank of stabilized mollusc samples beginning in 1981;

- organization and management of national and international collaborations through European conventions and international programs previously cited at the beginning of paragraph 4.1; and

- implementation of data quality management, which is a driver for achieving the "state of the art" in marine environmental chemical analyses.

Although the RNO was designed for environmental monitoring purposes, it has also performed annual monitoring for food safety purposes to classify the shellfish-farming areas, and has conducted discrete site-specific studies.

In 2008, IFREMER established ROCCH (formerly RNO) for the French Ministry of the Environment, although $\mathrm{ROCCH}$ is partly financed by water authorities. The main purpose of $\mathrm{ROCCH}$ is to address the chemical monitoring needs of the WFD, and the OSPAR and Barcelona international conventions. $\mathrm{ROCCH}$, contrary to RNO, performs chemical monitoring of WFD substances directly in the water, but, to the detriment of monitoring shellfish. In particular, the February surveys of shellfish have been discontinued. However as an annual peak in shellfish contamination was regularly observed, this change may be prejudicial for food safety monitoring, so, since 2008, DGAL has financed a February monitoring survey. The number of sampling points has been increased by $60 \%$ for this February survey to improve coverage of the shellfish farming areas. Similarly, the number of taxa monitored has been increased to also address farmed species. Analytical results of the 
monitoring are published no more than three months after the sampling, compared to ten months post-monitoring under the RNO system.

Up to the present, food safety monitoring has only applied to three trace elements. However, starting in 2011, DGAL and IFREMER will initiate monitoring for dioxins, dl-PCBs and benzo[a]pyrene, to comply with Regulation (EC) 1881/2006 (EC 2006c), and to follow the recommendations published in AFSSA's opinion of 21 March 2008 (AFSSA 2008a).

The monitoring work undertaken by RNO and $\mathrm{ROCCH}$ are described in Table 10 , in the context of the various conventions and directives.

\subsubsection{Examples of Contaminant Testing}

In this section, a coastal lagoon (Arcachon Bay, Bassin d'Arcachon in French) and an estuary (Bay of Seine) have been taken as examples:

\section{Bassin d'Arcachon}

The mean concentrations of lead, cadmium, mercury and other contaminants detected in Bassin d'Arcachon are shown in Table 11. The mean concentrations recorded by the RNO in oysters from Bassin d'Arcachon are $0.18 \pm 0.04 \mathrm{mg} \mathrm{kg}^{-1}$ fresh wt for lead, $0.23 \pm 0.09 \mathrm{mg} \mathrm{kg}^{-1}$ for cadmium and $0.03 \pm 0.01 \mathrm{mg} \mathrm{kg}^{-1}$ for mercury. These figures are well below the regulatory limits (Table 2). High concentrations of copper are found in oysters (24.51 \pm 9.69 $\mathrm{mg} \mathrm{kg}^{-1}$ fresh wt flesh). The concentrations have risen over the past 20 years, probably because copper has replaced the TBTs in anti-fouling paints (Claisse and Alzieu 1993).

In regard to the TBTs, mussels transplanted to oyster farms have revealed concentrations of approximately $30 \mathrm{\mu g} \mathrm{kg}^{-1}$ dry wt, and showed increases in July and August (Devier et al. 2005). No trace of TBTs has been detected in the water. However, in mussels transplanted to harbor areas, concentrations of 800 to $2400 \mathrm{\mu g} \mathrm{kg}^{-1}$ dry wt have been recorded, with peaks occurring between April and September. Devier et al. (2005) attribute this increase to spring and summer nautical activities. TBT concentrations measured in the surface waters of Arcachon harbor range between 2 and $7 \mathrm{ng} \mathrm{L}^{-1}$ (samples taken from May to August); the corresponding BCF values range from $2.8 \times 10^{5}$ to over $1.3 \times 10^{6}$. These are the highest $\mathrm{BCF}$ values recorded in the literature for mussels (Mytilus sp.). TBT levels of $400 \mu \mathrm{g} \mathrm{Sn} \mathrm{kg}{ }^{-1} \mathrm{dry}$ wt, measured in sediments, are responsible for the high contamination levels found in mussels, and result from sediment resuspension (Devier et al. 2005). The observed speed of TBT bioaccumulation is high, and is consistent with data in the literature (stabilization after 25 days). Devier et al. (2005) concluded that Arcachon harbor is severely contaminated by organotins, because of their persistence in sediments from use as an anti-fouling treatment for boats; the organotins continue as significant contaminants several years after their use has been banned. The concentrations recorded in mussels transplanted to the harbor highlight the role this hotspot plays in local contamination, and the hazard it represents for the entire Arcachon Bay. These data confirm the work of Auby and Maurer (2004), who revealed TBT levels (between 1997 and 2003) in Arcachon Bay waters near the harbor service station that ranged from 5.7 to $21.9 \mathrm{ng} \mathrm{L}^{-1}$. The toxic effects on plankton and molluscs associated with these TBT concentrations in seawater have been recorded by Alzieu et al. (1991) and Michel and Averty (1999). They reported that even for a TBT concentration in seawater of less than $1 \mathrm{ng} \mathrm{L}^{-1}$, the females of some gastropods may develop male sexual characteristics (imposex). At concentrations exceeding $1 \mathrm{ng} \mathrm{\textrm {L } ^ { - 1 }}$, diatom growth and zooplankton reproduction are restricted; above $2 \mathrm{ng} \mathrm{L}^{-1}$, oyster shells show calcification anomalies, and above $20 \mathrm{ng} \mathrm{L}^{-1}$, reproductive anomalies are observed in bivalves.

High levels of PAHs were measured in mussels transplanted in Arcachon harbor, with peaks occurring in May-June and August (the annual means at this site range from $1.45 \times 10^{6}$ to 
$1.62 \times 10^{6} \mathrm{pg} \mathrm{g}^{-1}$ dry wt, depending on the specific $\mathrm{PAH}$, with a maximum of $2.7 \times 10^{6} \mathrm{pg} \mathrm{g}^{-1}$ dry wt) (Devier et al. 2005).

Regarding indicator PCBs (sum of PCB 28, 52, 101, 118, 138, 153 and 180), the levels measured in mussels are low (annual means of 5.4 and $7 \times 10^{3} \mathrm{pg} \mathrm{g}^{-1}$ wet wt). Concentrations in oysters are similar, with $5.2 \pm 3.6 \times 10^{3} \mathrm{pg} \mathrm{g}^{-1}$ wet wt.

Twenty-one pesticidal and biocidal active substances have been detected in the waters of the Arcachon Bay during the summertime from 1999 to 2003, at concentrations ranging from a few $n g L^{-1}$ to several hundred $n g L^{-1}$. Most of these substances are herbicides, including some that are now banned (Auby and Maurer 2004). According to Auby and Maurer (2004), the presence of these substances may impact the development of the small phytoplankton on which oyster larvae feed, but probably do not affect oyster larval development.

The studies of Auby and Maurer (2004), and Devier et al. (2005) thus emphasize the need to monitor TBT and PAH contamination levels in shellfish farming areas of Arcachon Bay. Doing so will ensure that TBT and PAH pollution does not migrate from the harbor to the oyster and mussel farming areas.

The need to monitor TBT and PAH contamination levels in shellfish farming areas, as observed at Arcachon Bay, can be extended for the entire French coast, since organostannic and $\mathrm{PAH}$ compounds are present in similarly semi-enclosed waters elsewhere along the coast. The highest concentrations of TBTs and their degradation products are recorded in harbor areas, e.g., Brest $\left(1.5 \mathrm{mg} \mathrm{kg}^{-1}\right.$ of TBT) and Lorient $\left(0.44 \mathrm{mg} \mathrm{kg}^{-1}\right)$ on the Atlantic coast, and Gulf of Fos $\left(1.1 \mathrm{mg} \mathrm{kg}^{-1}\right)$, Toulon $\left(4.1 \mathrm{mg} \mathrm{kg}^{-1}\right)$ and Gulf of Saint-Tropez (1.55 mg $\mathrm{kg}^{-1}$ ) (Averty et al. 2005) on the Mediterranean coast. Relatively high levels of TBT and PAH are also found in other coastal areas such as the Seine estuary, the Basque coast and Thau Lagoon.

\section{Bay of Seine}

A study of metal contamination of the main marketed species in Bay of Seine was conducted in 2000. The aim was to assess levels of contamination by lead, mercury, cadmium, chromium and silver in five commercial species of interest: whelk, king scallop, plaice/sole, cod and rock salmon. The study (Chiffoleau et al. 2002) shows that whelks were heavily contaminated with cadmium - above the French regulatory limit, in very large specimens (over $70 \mathrm{~mm}$ ). Based on this finding, a local decree was issued in July 2002, classifying whelks of over $70 \mathrm{~mm}$ as 'Class D' (French classification grade designating that harvest is prohibited) and whelks of less than $70 \mathrm{~mm}$ as "provisional Class A", throughout Bay of Seine and the coasts of Seine Maritime district. In 2002 and 2003, whelk sampling was intensified, particularly for small specimens, to determine the size, on average, above which the $2 \mathrm{mg} \mathrm{Cd}$ $\mathrm{kg}^{-1}$ wet wt threshold (French decree of 21 May 1999) would be exceeded.

The mean concentrations of cadmium, mercury, lead and benzo[a]pyrene in mussels are given in Table 12. The concentrations of these four contaminants are below the regulatory limits (Table 2).

\subsubsection{Active Environmental Biomonitoring: a Promising Procedure for the Future}

Researchers have been conducting active biomonitoring using various shellfish species for several years. For example, the study of Devier et al. (2005) used transplantation experiments. Active biomonitoring has a number of advantages over conventional monitoring (Andral et al. 2004). The transplanted shellfish have a known history, their exposure time is controlled, the siting of the station is chosen independently of bathymetry, and each 
specimen's position in the water column is controlled. Measurements are optimized, because samples are more homogeneous owing to the selection of specimens for the experiment (parental origin, size, age, healthy site of origin, etc.). There are some constraints, such as complicated logistics, data interpretation that depends on the trophic and physico-chemical variability of the destination site; additional biometric parameters must therefore be measured. The abundant literature in this field (Berthet et al. 2008; De Kock and Kramer 1994; Mourgaud et al. 2002) provides transplantation protocols that include the time required to establish equilibrium with the new environment, the initial stress and the trophic factors of the destination site.

Transplantation is a promising procedure for the future because of numerous benefits already cited, nevertheless, one aspect thus far neglected is the possibility of theft by illintentioned people.

\subsection{Chemical Monitoring for Marketed Shellfish}

Those who produce and/or market bivalve molluscs are subject to self-inspection and mandatory product traceability to provide information on quality, including analysis of chemical contaminants and shellfish mortality. For marketed shellfish, the public health authorities responsible for official controls must follow the provisions of the Annex II of Regulation (EC) 854/2004 (EC 2004c). The French Directorate General for Food (DGALdirection générale de l'alimentation) is in charge of these controls and has drawn up annual monitoring programs since 1998 to assess the contamination levels of marketed shellfish.

\subsubsection{Self-inspection}

Self-inspection is a key tool for shellfish operators to optimize their effectiveness in meeting the requirements of the Hygiene Package. In addition, self inspection during production, transportation, purification, maturing and finishing also ensures the food safety of shellfish when they reach the consumer. Self-inspection is carried out for microbiological and chemical contaminants, both in the water and in the shellfish. Sampling is performed by thirdparty professionals who send their samples to a laboratory of their choice.

\subsubsection{Monitoring and Management of Shellfish Mortality}

Operators must report each event of mortality that exceeds $20 \%$ of individuals, within a 15 day period to the responsible authority. IFREMER then conducts a survey to determine the cause of the mortality, and whether it has an environmental, microbiological (often involving Vibrio, viruses, fungi or parasites) or a zootechnical origin. For animal health reasons, IFREMER produces periodic reports on national and regional oyster mortality, through the Mollusc Pathology Network (REPAMO - Réseau de PAthologie des MOllusques), and other organizations. Mortality occurs in patches within an area and generally affects only one species. It is thought to be multifactorial (Oyster Summer Mortality programme (i.e., MOREST Mortalité ESTivale d'huîtres and REPAMO), and involve oyster physiology, environmental factors (it does not occur below a temperature of $19^{\circ} \mathrm{C}$ ) and/or aggravating factors (viruses, bacteria) (Samain and McCombie 2008). According to Gagnaire et al. (2006), pesticides may be among the triggering factors. 
The epidemiological aspect of these die-offs and the zootechnical and environmental context provide guidelines for diagnosis. For example, if several species are affected simultaneously, an environmental or toxic origin will be strongly suspected. Blooms of Gymnodinium spp., transfer stress and anoxia are known to cause die-offs. However, it is difficult to precisely identify causes, because operators sometimes take their samples at intervals of two weeks or more, (e.g., where concessions are accessible only during low spring tides). These mortality events also require dealing with decomposing shellfish, which can affect the microbiological quality of the water in a confined environment. Summer mortality of Pacific oysters (C. gigas) on the French coast is regularly reported, but has not endangered this species, which was considered to be invasive up until three years ago. Recurrent seasonal mortality has also been reported in Ruditapes clams and cockles, but not at the same time of year (in spring for Ruditapes clams, after stormy episodes for cockles). In 2008 and 2009, there was high mortality among Pacific oysters in France. Laboratory experiments have shown that certain pollutants can affect the genetic, immunity and trophic characteristics of oysters; in 2009, the combined presence of the OsHV-1 virus and the bacterium Vibrio splendidus seems to have played a major part in the mortality incident (Sauvage et al. 2009)

No oyster pathogen is known to also be pathogenic for humans. In some cases of abnormal mortality in marine species (e.g., several species suddenly, simultaneously and massively affected), a more thorough toxicological investigation may be undertaken to test for pesticides or biocides.

\subsubsection{Monitoring Program for Chemical Contaminants in Marketed Shellfish}

Two offices of the DGAL are involved in monitoring chemicals in shellfish: (1) the Office for the Quality and Safety of Food Products from Fresh and Marine Waters (BQSPMED Bureau de la Qualité Sanitaire des Produits de la Mer et d'Eau Douce), responsible for monitoring chemical contaminants in bivalve molluscs and (2) the Office of Food and Biotechnology Regulations (BRAB - Bureau de la Réglementation Alimentaire et des Biotechnologies), responsible for the EU dioxin monitoring program. The International Health and Safety Coordination Mission ((MCSI - Mission de Coordination Sanitaire Internationale, part of DGAL) is also involved by sampling imports. The screened chemical contaminants are trace elements (lead, cadmium, mercury), indicator PCBs (7 congeners: 28, 52, 101, 118, 138, 153 and 180) and PAHs (15 since 2006). In earlier monitoring and control programs (1998-2002), pesticides and antibiotics (EC 2000) were tested. The number of bivalve mollusc samples to be tested each year, under the chemical contaminants monitoring program, is 400 altogether (all species and all chemical contaminants); this number includes farmed shellfish (oyster, mussel, cockle and Ruditapes clams) and wild populations of pectinids fished in French waters.

The local veterinary authorities (DDSV - Direction Départementale des Services Vétérinaires) communicates confirmed positive results to DGAL without delay to the local Maritime Affairs authorities (DDAM - Direction Départementale des Affaires Maritimes) and to IFREMER. An investigation is then carried out to identify the contamination source and any corrective measures that are required.

For cadmium, this process has brought several non-compliances to light. In Table 13, the first screening gives some non-compliance data for cadmium which were refined by a second analysis using a more sophisticated method, and by taking into account deviations from the standard. In view of the results from 2005, DGAL conducted a control study that had five samplings in March 2006. The goal was to check the level of contamination in problem areas and in the smaller neighbouring area of Pertuis d'Antioche (French Atlantic coast). These samplings also resulted in four non-compliant results for cadmium, and they were confirmed by AFSSA/LERQAP (two from the Pertuis Breton (French Atlantic coast) and two from 
Arcachon Bay). Because of these results, imposition of possible management measures are under examination in collaboration between the French Directorate General for Health (DGS - Direction Générale de la Santé) and the Directorate for Marine Fisheries, and Aquaculture (DPMA - Direction des Pêches Maritimes et de l'Aquaculture).

With respect to the specific DGAL monitoring programs conducted in 2009 , the presence of lead $(\mathrm{Pb})$, cadmium $(\mathrm{Cd})$ and mercury $(\mathrm{Hg})$ concentrations in the white and dark meats of 108 batches of crustaceans (lobsters, spider crabs, common crabs, swimming crabs and king crabs) were found. These organisms, under investigation by the French National Reference Laboratory (NRL), were collected in France between April and December, 2009, and in marine gastropods (common winkles, common whelk, abalone and murex), echinoderms (purple sea urchin and black sea cucumber) and tunicates (ascidians) (Noël et al. 2011, in press). The results show mean concentrations for crustacean white meat of $0.041,0.132$ and $0.128 \mathrm{mg} \mathrm{kg}^{-1}$ for $\mathrm{Pb}, \mathrm{Cd}$ and $\mathrm{Hg}$, respectively. These values were always lower than the European legislation maximum level of $0.50 \mathrm{mg} \mathrm{kg}^{-1} \mathrm{Cd}$. The concentration in the dark meat of common crabs (mean concentration: $11.8 \mathrm{mg} \mathrm{kg}^{-1}$ and maximum of $14.3 \mathrm{mg}$ $\mathrm{kg}^{-1}$ ) is well above the observed levels for white meat. The results for gastropods, echinoderms and tunicates show that the highest levels of $\mathrm{Hg}$ and $\mathrm{Cd}$ were found in murex, $0.185 \mathrm{mg} \mathrm{kg}^{-1}$ and $0.853 \mathrm{mg} \mathrm{kg}^{-1}$, respectively; whereas the highest level of $\mathrm{Pb}$ was detected in ascidians $\left(0.505 \mathrm{mg} \mathrm{kg}^{-1}\right)$. $\mathrm{Hg}$ and $\mathrm{Pb}$ concentrations were systematically below the maximum regulatory levels $\left(0.5 \mathrm{mg} \mathrm{Hg} \mathrm{kg}^{-1}\right.$ and $1.5 \mathrm{mg} \mathrm{Pb} \mathrm{kg}^{-1}$ wet wt). For $\mathrm{Cd}$, only two samples of murex $\left(2.09 \pm 0.42 \mathrm{mg} \mathrm{kg}^{-1}\right.$ and $\left.2.33 \pm 0.46 \mathrm{mg} \mathrm{kg}^{-1}\right)$ exceeded the French maximum level of $2.0 \mathrm{mg} \mathrm{kg}^{-1}$ wet wt.

Other of the data on contaminants contained in marketed shellfish are presented in Tables 3 and 6.

\subsubsection{European Data on Chemical Contamination of Shellfish}

There is no specific EU reference laboratory (EU-RL) for monitoring chemical contaminants in shellfish. However, there are four EU-RLs that test for lead, cadmium, mercury, PAHs, dioxins and PCBs in animal tissues as indicated in Regulation (EC) N776/2006 (EC 2006a).

Chemical contamination levels in shellfish are monitored in many national and international surveys. However, many of these are not published. It would be useful for many researchers and governmental personnel to bring these scientific data together in a single national or European database that could be accessed through the internet.

\section{Impact on Humans}

Health risks associated with chemical contaminants are difficult to assess, owing to the fact that many produce only long-term action (chronic risk), and such contaminants reach humans through so many different sources (food, water, air, occupational, etc.). To assess the health impact of contaminated shellfish consumed by humans, exposure has to be estimated from contamination levels and consumption data. 


\subsection{Consumption Data for the General Population (INCA 2 2009)}

Data on food consumption for the general population (including consumers and nonconsumers of shellfish) may be taken from the INCA 2 (2009) survey (Enquête Individuelle et Nationale sur la Consommation Alimentaire), conducted in 2005-2007 by the Food Consumption and Nutritional Epidemiology Unit (OCA-EN) at AFSSA. In this survey, all types of food intake was recorded by respondents over a period of one full week. To account for seasonal effects, the survey was carried out in four phases spread over a period of one year. Food consumption data were obtained from consumption diaries that respondents kept over the targeted seven-consecutive-day period; in their diaries respondents identified the foodstuffs and portions that were shown in a booklet of photographs (Suvimax 2002). The survey included 4000 adults and children that were representative of the French population. To ensure that the sample was nationally representative, it was stratified by region of residence and town size, and a quota method was used for age, sex, occupation, sociooccupational category and size of household. The adult sample included 2624 individuals aged 18 and over. A special method was used to exclude bias resulting from underestimation of food consumption by some respondents; those for whom the ratio between calories consumed and the basal metabolism, calculated using the Schofield method, was below a certain threshold, were excluded from the calculations (706 were excluded). The collection of "normal" adults thus included 1918 individuals. The sample of children included 1455 individuals aged 3 to 17 . This sample was not adjusted, because there was no formula for identifying low-food-consuming subjects among children. In this survey, only the edible parts of foodstuffs were used to establish quantities consumed. The food groups counted as 'solid foods' included all food groups in the INCA 2 (2009) nomenclature except for milk, water, soft drinks, alcoholic drinks, hot drinks and soups.

At the most detailed level of the INCA 2 (2009) nomenclature, the reliability of the data for foods such as molluscs is not certain, because consumption was recorded for only one week. Amounts consumed were very low (Table 14). For comparison, Table 14 gives data on the percent consumption of meat and fish by INCA 2 (2009) survey respondents. Mean daily consumption of shellfish, in the general population, was estimated to be $4.5 \mathrm{~g}$ in adults; this value varied widely by region and season of the year. Using this consumption level, Shellfish consumption represented $0.16 \%$ of overall solid food intake. However, the INCA 2 survey (2009) was not well-suited to estimating shellfish consumption, because it included only a small number of shellfish consumers.

In conclusion, consumption of bivalve molluscs in France contributes little to the general population's overall food intake. Notwithstanding this conclusion, for the sake of regular shellfish consumers, continuing vigilance is necessary.

\subsection{Consumption Data for High Consumers of Seafood (CALIPSO)}

After the first INCA study (INCA1 1999), a specific work, called CALIPSO, was devoted to high consumers, i.e., adults who eat fish or seafood products at least twice a week (Leblanc et al. 2006). In Table 15 we present the data on mollusc consumption among high consumers of seafood products that were included in the CALIPSO survey ( $n=1011$ adults, including 246 men aged 18 to 64, 641 women aged 18 to 64, and 124 persons aged 65 and over). The results are given as means across the four sites studied, without distinction for age or gender (Leblanc et al. 2006).

Consumed bivalve species included cockle, mussel, king scallop, queen scallop, other scallops, razor clam, Ruditapes clams, other clams, oysters, warty venus and wedge shell. Consumed gastropods included winkles, whelks, abalones and limpets. The only echinoderm eaten in France is the sea urchin and the only tunicate eaten is the sea squirt. 
In CALIPSO, mean consumption of bivalve molluscs among adults is estimated at $153 \mathrm{~g}$ per week $\left(8 \mathrm{~kg} \mathrm{yr}^{-1}\right)$. The highest mean consumption is for king scallops (39 $\mathrm{g}_{\text {week }}{ }^{-1}$ ), followed

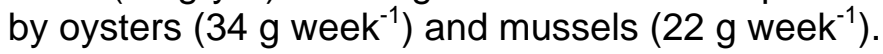

Overall, these high consumers of seafood products eat, on average, twice the quantity of bivalve molluscs as do the shellfish consumers in the general population (INCA 2 2009); this is about the same level as the mean consumption of fish in the general population.

\subsection{Exposure to Contaminants via Shellfish Consumption}

\section{Cadmium}

In France, CALIPSO data show that the mean cadmium intake from shellfish is $1.26 \mu \mathrm{g}$ week $^{-1}$ in adults (Leblanc et al. 2005, 2006), which is about half of the new tolerable weekly intake (TWI) value that was recently revised by the European Food Safety Authority (EFSA); this value was revised from 7 to $2.5 \mu \mathrm{g} \mathrm{kg}^{-1}$ bwt per week (EFSA 2009). A recent PTMI (provisional tolerable weekly intake) value was given by JECFA $\left(25 \mu \mathrm{g} \mathrm{kg}^{-1}\right.$ body wt mon ${ }^{-1}$ ); this value corresponds closely to a PTWI value of $5.3 \mu \mathrm{g} \mathrm{kg}^{-1}$ bwt per week. Shellfish consumed by adult men, who are high seafood consumers, leads to a cadmium intake of more than twice that of the average total intake from food, in non-smoking adult men (EAT total diet survey by AFSSA). The cadmium intake varies from $8.2,10$ and $23 \%$ of the PTWI, depending on the threshold that is selected (Table 3). The contribution of shellfish differs between regions. The shellfish that contribute most to cadmium intake by humans (CALIPSO survey) are king scallops (14\% in Le Havre and $20 \%$ in Toulon), whelks (21\%), scallops (19\%) and oysters (11\% in La Rochelle) (Leblanc et al. 2006).

\section{Lead}

In France, the mean intake of lead has fallen considerably in recent years. In 2005, the EAT survey indicated an average intake from food of $18 \mu \mathrm{g}_{\text {day }}{ }^{-1}$ per adult, which amounts to $7 \%$ of the PTWI value set by the Joint FAO/WHO Expert Committee on Food Additives (JECFA) in 1986 (Leblanc et al. 2005). The mean lead intake from shellfish (CALIPSO survey) is 0.26 $\mu \mathrm{g} \mathrm{kg} \mathrm{bwt}{ }^{-1}$ day $^{-1}$ in adults (from Leblanc et al. 2005, 2006). However, in June 2010, the JECFA concluded that the PTWI could no longer be considered health protective and withdrew it (JECFA 2010b). EFSA came to the same conclusion in its opinion of March 2010 (EFSA 2010). Consumption of seafood (fresh fish, crustaceans and molluscs) accounts for $3 \%$ to $11 \%$ of lead intake from total food. Shellfish contribute $0.7 \mu \mathrm{g}$ day $^{-1}$ of that intake. According to the CALIPSO survey, the main shellfish concerned are king scallops in Le Havre (22\%), mussels in La Rochelle (16\%) and sea urchins in Toulon (14\%) (Leblanc et al. 2006).

\section{Mercury}

In seafood products, mercury is mainly present as methylmercury (see section 5.4). For methylmercury (MeHg), EFSA and AFSSA have both acknowledged that some population groups are particularly at risk: pregnant and breast-feeding women, very young children, fishing communities in heavily contaminated areas (EFSA 2004a; AFSSA 2004). Both agencies recommend that special information be aimed at these groups to encourage them to eat a wider range of fish species. In France, exposure study results show that values are two times lower than the PTWI (of $4 \mu \mathrm{g}$ ) for inorganic $\mathrm{Hg} \mathrm{kg}^{-1}$ body weight. In adult males, who are high seafood consumers, the CALIPSO data suggest that shellfish result in an average intake of $0.47 \mu \mathrm{g} \mathrm{day}^{-1}$ of $\mathrm{MeHg}$ per adult, which approaches $1.2 \%$ of the PTWI 
(Leblanc et al. 2006). In general, fish contribute $86 \%$, and molluscs and crustaceans $13 \%$ of MeHg exposure (EAT 2004 ; Leblanc et al. 2005 ; Sirot et al. 2008).

\section{Arsenic}

In 2003, the mean total arsenic intake in Europe was estimated at $125 \mu \mathrm{g} \mathrm{day}^{-1}$ in adults (SCOOP 2004); seafood accounted for over $50 \%$ of this exposure. The mean arsenic intake from shellfish from CALIPSO data is $84 \mu \mathrm{g} \mathrm{kg} \mathrm{bw}^{-1}$ week $^{-1}$ in adults (Leblanc et al. 2005, 2006). The seafoods that contribute most to the French population's inorganic arsenic exposure are king scallops (8.6\% of intake from seafood) and oysters (7.0\%) (Sirot et al. 2009). In the general population, shellfish contribute $0.2 \%$ of the PTWI for total arsenic (EAT 2004 ; Leblanc et al. 2005). However, it was noted in the $72^{\text {nd }}$ JECFA committee meeting that the PTWI of $15 \mu \mathrm{g} \mathrm{kg} \mathrm{bwt}{ }^{-1}$ (equivalent to $2.1 \mu \mathrm{g} \mathrm{kg}$ bwt $^{-1}$ per day) approaches the benchmark dose lower limit $\left(\mathrm{BMDL}_{05}\right)$, and therefore the PTWI is no longer appropriate. The committee withdrew the previous PTWI (JECFA 2010a). EFSA concluded that the overall range of $B M D L_{01}$ values of 0.3 to $8 \mu \mathrm{gg}^{-1}$ bwt per day should be used, instead of a single reference point, in characterizing the risk of inorganic arsenic (EFSA 2009).

\section{Organostannic Compounds}

In France, the average exposure of high seafood consumers to nine organostannic compounds is far below the tolerable daily intake. This intake is 8 to $19 \%$ of the TDI of $0.1 \mu \mathrm{g}$ Sn $\mathrm{kg}^{-1}$ bwt set by EFSA for the combined total from the following Sn compounds: tributyltin (TBT), dibutyltin (DBT), triphenyltin (TPT) and di-octyltin (DOT) (AFSSA 2006; EFSA 2004b; Guerin et al. 2007).

\section{Dioxins}

The mean dioxin intake from shellfish for the sum of PCDD/Fs and dl-PCBs is $18.7 \mu \mathrm{g} \cdot \mathrm{kg}^{-1}$ bwt.week $^{-1}$ in adults (from CALIPSO data; Leblanc et al. 2006). However, it is important to note that these values are overestimated, because cooking seafood reduces the PCDD content (Hori et al. 2005). The shellfish contribution to the tolerable intake is low $(5.73 \%$ for all species).

\section{PCBs}

Only $28 \%$ of high seafood consumers show indicator PCB (sum of PCB 28, 52, 101, 118, 153 and 180) levels below the TDI of $0.02 \mu \mathrm{g} \mathrm{kg}^{-1}$ bwt day ${ }^{-1}$, the average being $0.40 \pm 0.55$ $\mu \mathrm{g} \mathrm{kg}^{-1}$ bwt day ${ }^{-1}$. Shellfish only contribute $9.5 \%$ to the TDI, $45 \%$ of which comes from the king scallop (Leblanc et al. 2006).

\section{Body Burdens for these Trace Elements}

The CALIPSO survey provides data on the body burdens (saturation) of high seafood consumers (adults) in lead, cadmium, mercury and arsenic. However, from these data, it is not possible to determine how much shellfish contributes to the body burden. Concentrations of these chemical contaminants, measured in blood and urine, are compared with a 'basal value'. This basal value is defined as the value found at the $95^{\text {th }}$ percentile (P95) of the general French population that is not occupationally exposed. This value should not be interpreted as a maximum allowable quantity, but it makes it possible to identify a possible body overload. In conclusion, high seafood consumers do not display a significantly higher body burden than does the P95 of the general population for lead, cadmium or mercury. For lead, $6 \%$ of high seafood consumers exceed the basal value of $90 \mu \mathrm{g} \mathrm{L}^{-1}$ for men, and $70 \mu \mathrm{g}$ $\mathrm{L}^{-1}$ for women. There were no observed blood concentration of lead $>200 \mu \mathrm{g} \mathrm{L}^{-1}$, the concentration above which a person is put under medical observation. For cadmium, fewer 
than $5 \%$ of individuals retained cadmium levels in urine higher than the basal value of $2 \mathrm{mg}$ $\mathrm{kg}^{-1}$ creatinine. For mercury, only $3 \%$ of the values exceeded the basal value of $10 \mu \mathrm{g} \mathrm{L}^{-1}$ in blood. No signs of a health risk impairment were identified for any of these three contaminants. However, $22 \%$ of individuals displayed inorganic arsenic levels that exceeded the basal concentration in urine of $10 \mathrm{mg} \mathrm{kg}^{-1}$ creatinine, which is the P95 value for the general population (INRS 2010; Pillière and Conso 2007).

We conclude from the foregoing that, for high seafood consumers, the contribution of shellfish to inorganic contaminants was 1 to $10 \%$ of TWI or PTWI for Cd, MeHg, and Sn (up to $19 \%$ for Sn), and the arsenic body burden was higher for $22 \%$ of individuals studied. These percentages will differ if the established effective regulatory threshold is different (Table 3).

\subsection{Health Risk Assessment Uncertainty from Contaminant Bioavailability and Speciation Effects}

The regulatory limits for lead, cadmium and mercury that were established in Regulation (EC) 1881/2006 (EC 2006c) are based on the total concentrations of them that exists in foodstuffs. However, only the bioavailable fraction can be transferred from shellfish to humans, during digestion. This fraction is influenced by several factors, and is rarely $100 \%$ of the amount present.

For mercury, it is the methylated form that predominates as a seafood residue, and this organic form is also the most toxic (Nakagawa et al. 1997 ; Storelli et al. 1998). A study of oysters and mussels sampled in 1996 under the RNO sampling program, show $\mathrm{MeHg} / \mathrm{THg}$ (total $\mathrm{Hg}$ ) ratios ranging from $11 \%$ to $88 \%$. No notable differences were observed between the two mercury species, but there was considerable geographical variability (Claisse et al. 2001). Bioamplification has been observed in organic forms of mercury, with an increase in concentration at each trophic step in the food chain. In the CALIPSO survey, $\mathrm{MeHg} / \mathrm{THg}$ ratios in shellfish ranged from $50 \%$ to $100 \%$ (Leblanc et al. 2006).

The toxicity of arsenic depends on its chemical form and its bioavailability. Inorganic forms of arsenic are more toxic than are the organic forms (Michel 1993 ; Sharma and Sohn 2009). A high proportion of the organic arsenic in seafood is in weakly toxic forms such as arsenobetaine and trimethylarsine. These forms are rapidly excreted (ATSDR 2007; Liber et al. 2006). According to the WHO, there are some (but limited) data showing that $25 \%$ of total arsenic in foodstuffs is in inorganic form. The data from a French study (Noël et al. 2003) suggest that, in fishery products, 5 to $10 \%$ of arsenic is in inorganic form, whereas the CALIPSO study gives figures ranging from 0.1 to $3.5 \%$ in fish, and from 0.1 to $6.7 \%$ in shellfish (Sirot et al. 2009). However, the percentage of inorganic arsenic is quite variable in fish and shellfish, and data from the international literature indicate that the percentage of inorganic arsenic in marine/estuarine finfish does not exceed $7.3 \%$. However, in shellfish, it can reach $25 \%$ in organisms from presumably uncontaminated areas, although there are few data available for freshwater organisms. However, percentages can be much higher in organisms from contaminated areas and in seaweed (Schoof and Yager 2007; Lorenzana et al. 2009).

For mercury and arsenic it is thus difficult to conclude whether or not they pose a public health risk, when only the total levels present are given, and without differentiating between the proportion that is inorganic and organic.

Efforts have been made in various studies to quantify the bioavailability, or rather bioaccessibility, of trace elements that are accumulated by bivalves (He et al. 2010; Metian et al. 2009). Amiard et al. (2008) simulated human digestion in vitro with the flesh of naturally 
contaminated oysters, whelks, mussels, scallop species and Ruditapes clams. The total concentrations in these samples exceeded regulatory limits for the following (Amiard et al. 2008):

- $\quad \mathrm{Cd}$, in whelks (B. undatum) purchased in France, and in the adductor muscles of noble scallops (Chlamys nobilis) from Hong Kong;

- $\quad \mathrm{Pb}$ in oysters (O. edulis) from Restronguet Creek, UK, Zn in whelks, and

- $\mathrm{Cu}$ and $\mathrm{Zn}$ in all samples of oysters from contaminated sites.

However, these comparisons are based on Australian and Asian standards that Europe does not recognize. If the concentrations recorded were indeed bioaccessible concentrations, only the levels of $\mathrm{Cd}$ in scallop species and $\mathrm{Zn}$ in whelks would be acceptable.

Although levels of arsenic in the urine and more specifically inorganic arsenic are satisfactory biomarkers for occupational and drinking water exposures, the literature data show that consumption of seafood gives variable results. The amount of total or inorganic arsenic in the urine is, therefore, not a relevant or usable indicator of the intensity of exposure to the most toxic forms of arsenic ingested with food, and with seafood in particular. To assess the health risk of ingesting arsenic via seafood, the species of arsenic must be taken into account, because there are significant differences in toxicity among the different chemical species. For example, the mean LD $_{50}$ (lethal dose, 50\%) in rats, expressed in $\mathrm{mg} \mathrm{kg}^{-1}$ bwt, is 14 for potassium arsenite, 20 for calcium arsenate, 700 to 1800 for MMA (monomethylarsonic acid), 700 to 2600 for DMA (dimethylarsinic acid) and over 10,000 for arsenobetaine. In drinking water, arsenic is mainly found in the inorganic form, as the oxide anions arsenite and arseniate. The main foodstuffs supplying inorganic arsenic are cereals, flour and raw rice (Schoof et al. 1999), but seafoods contain several organic arsenic compounds and are a major food source of arsenic (Francesconi and Edmonds 1998 ; Munoz et al. 2000). Arsenic in fish, most shellfish and many crustaceans is mainly in the form of arsenobetaine, whose very weak toxicity has been established (Kaise et al. 1985 ; Sabbioni et al. 1991). Arsenobetaine is quickly excreted in an unaltered form in the urine ( $70 \%$ in 3 days) (Cannon et al. 1983), and does not react with the reagents used in urinary tests. Hence, arsenobetaine is clearly differentiated during arsenic speciation in the urine, and several experimental studies have shown that its consumption does not significantly alter the parameters of urine analyses for inorganic arsenic (Buchet et al. 1996 ; Heinrich-Ramm et al. 2002 ; Hsueh et al. 2002).

Algae, bivalves, crustaceans and fish all contain derivatives of ribose and arsenic called arsenoribosides (arsenosugars), which are metabolized and excreted in the urine, particularly as DMA $(\mathrm{V})$, and in the form of dimethyloxarsylethanol and trimethylarsine oxide (Francesconi et al. 2002 ; Ma \& Le 1998 ; Wei et al. 2003). It has been observed that ingestion of arsenoribosides via food invalidates the use of urine testing for inorganic arsenic derivatives, and as an exposure marker for these derivatives. As a result, these tests cannot satisfactorily reflect intake of inorganic arsenic (for which there is a risk of excess cancers) in individuals consuming seafood (Borak and Hosgood 2007 ; Heirich-Ramm et al. 2002 ; Ma and Le 1998). Considering that arsenic from seafood is usually eliminated within 3 days (Crecelius 1977 ; Freeman et al. 1979), it is recommended that urine tests for inorganic arsenic should occur at least 3 or 4 days after any seafood consumption (Foa et al. 1984 ; Kales et al. 2006).

As previously mentioned, health risks associated with chemical contaminants are difficult to assess because the risks they pose are normally of a chronic nature, and their sources of human exposure are numerous. Therefore, it is not possible to attribute a high body burden specifically to shellfish consumption, even though seafood is a major contributor of some contaminants, especially arsenic and mercury. 


\section{Conclusions}

The major conclusions we have reached from compiling and reviewing the literature cogent to the topic of this paper are as follows:

- Both organic and inorganic chemicals have been identified as residual chemical contaminants in shellfish. Some contaminants, particularly metals, dioxins, dl-PCBs and $\mathrm{PAH}$ that appear as residues in molluscs, pose a potential hazard to consumers, which has resulted in European regulatory limits being established for them.

- To protect shellfish from chemical contamination, shellfish production and commercialization are managed according to safe practices which are under the European "Hygiene Package" regulations. Product quality is maintained by controlling facilities, tracking major steps in shellfish production and ensuring that defective batches are kept from the market. Such regulation ensures greater transparency and product quality for consumers. However, limits to regulating shellfish production also exist, because, in France, it is difficult to trace all production steps of living shellfish from the earliest to latest stages, particularly for oysters, wherein the same oyster may be successively raised at facilities in different areas.

- Although monitoring results show few non-conformities, the samplings that are made cannot be considered as representing all shellfish production in France, because the numbers of samples taken are limited. In addition, when residue levels are exceeded, they normally occur in oysters and mussels, which are the most commonly eaten species. Hence, self-inspection by producers, enforcement of compliance with good practices and regular checks on production are indispensable additional measures to ensure food safety

- Last but not least, is that the chemical monitoring network that has been set up in France (the RNO program and its successor ROCCH) to screen for contaminants clearly shows that there is low chemical contamination of molluscs, and of seawater in which the molluscs live. Moreover, when shellfish contamination occurs, it poses a generally low risk to the general French population, because the proportion of the diet that shellfish constitutes is low. The exceptions are when contaminants reach those people who are either high-consumers of shellfish, or are a more susceptible population, such as pregnant and breast-feeding women and very young children. Appropriate research programs should first be developed to protect these more susceptible categories of the population.

To improve chemical safety of shellfish, some suggestions can be given and they concern:

- the relaying (depuration) program currently used to purify shellfish of microbiological contamination before commercialisation, which should be further researched to determine if and how chemical residues in shellfish could be similarly reduced before consumption. The alternative that has been used, to date, i.e., closing contaminated areas for long time periods results in significant economic losses

- the monitoring of farmed shellfish which should be extended to other chemicals that are suspected to present a consumer risk, including arsenic, which the CALIPSO study disclosed to have high consumer urine levels, and intensive monitoring for cadmium, which was abnormally detected in some shellfish in 2009. We would also suggest monitoring for TBT and PAHs contamination levels, to ensure that these chemicals do not migrate from the harbor to oyster farms, as was observed to occur 
Finally, from the data assembled in this review, we conclude that there is a strong argument not to curtail existing monitoring programs in edible shellfish. The major reason for continuing monitoring activities is that great variability exists in the magnitude to which different contaminants in shellfish bioconcentrate. Both environmental and species parameters are known to affect the degree of bioconcentration and bioaccumulation of potentially harmful residues, and, moreover residue loads are affected by the season during which the shellfish are harvested. Therefore, under equal conditions of environmental contamination, some species do exceed the European regulatory limits, whereas others do not. These variabilities explain the necessity of why monitoring was extended to farmed shellfish species by the $\mathrm{ROCCH}$, and why monitoring activities should continue.

\section{Summary}

In this review, we address the identification of residual chemical hazards in shellfish collected from the marine environment or in marketed shellfish. Data, assembled on the concentration of contaminants detected, was compared with the appropriate regulatory and food safety standards. Moreover, data on human exposure and body burden levels were evaluated in the context of potential health risks.

Shellfish farming is a common industry along European coasts. The primary types of shellfish consumed in France are oysters, mussels, king scallops, winkles, whelks, cockles, clams and other scallops. Shellfish filter large volumes of water to extract their food, and are excellent bioaccumulators. Metals and other pollutants that exist in the marine environment partition into particular organs, according to their individual chemical characteristics. In shellfish, accumulation often occurs in the digestive gland, which plays a role in assimilation, excretion and detoxification of contaminants. The concentrations of chemical contaminants in bivalve molluscs are known to fluctuate with the seasons.

European regulations limit the amount and type of contaminants that can appear in foodstuffs. Current European standards regulate the levels of microbiological agents, phycotoxins and some chemical contaminants in food. Since 2006, these regulations have been compiled into the 'Hygiene Package'. Bivalve molluscs must comply with maximum levels of certain contaminants as follows: lead $\left(1.5 \mathrm{mg} \mathrm{kg}^{-1}\right)$, cadmium $\left(1 \mathrm{mg} \mathrm{kg}^{-1}\right)$, mercury $\left(0.5 \mathrm{mg} \mathrm{kg}^{-1}\right)$, dioxins $\left(4 \mathrm{pg} \mathrm{g}^{-1}\right.$ and dioxins + dl-PCBs $\left.8 \mathrm{pg} \mathrm{g}^{-1}\right)$ and benzo[a]pyrene $\left(10 \mathrm{\mu g} \mathrm{kg}^{-}\right.$ $\left.{ }^{1}\right)$.

In this review, we identify the levels of major contaminants that exist in shellfish (collected from the marine environment and/or in marketed shellfish). The following contaminants are among those that are profiled: $\mathrm{Cd}, \mathrm{Pb}, \mathrm{Hg}, \mathrm{As}, \mathrm{Ni}, \mathrm{Cr}, \mathrm{V}, \mathrm{Mn}, \mathrm{Cu}, \mathrm{Zn}, \mathrm{Co}, \mathrm{Se}, \mathrm{Mg}, \mathrm{Mo}$, radionuclides, benzo[a]pyrene, PCBs, dioxins and furans, PAHs, TBT, HCB, dieldrin, DDT, lindane, triazines, PBDE, and chlorinated paraffins.

In France, the results of contaminant monitoring have indicated that $\mathrm{Cd}$, but not lead $(<0.26$ $\left.\mathrm{mg} \mathrm{kg}^{-1}\right)$ or mercury $\left(<0.003 \mathrm{mg} \mathrm{kg}^{-1}\right)$, have had some non-compliances. Detections for PCBs and dioxins in shellfish were far below the regulatory thresholds in oysters $\left(<0.6 \mathrm{pg} \mathrm{g}^{-}\right.$ $\left.{ }^{1}\right)$, mussels $\left(<0.6 \mathrm{pg} \mathrm{g}^{-1}\right)$ and king scallops $\left(<0.4 \mathrm{pg} \mathrm{g}^{-1}\right)$. The benzo[a]pyrene concentration in marketed mussels and those coming from farmed shellfish do not exceed the regulatory threshold. Some monitoring data are available on shellfish flesh contamination for unregulated organic contaminants. 
Of about a hundred existing organostannic compounds, residues of the mono-, di- and tributyl tin (MBT, DBT and TBT) and mono-, di- and tri-phenyl tin compounds (MPT, DPT and TPT) are the most frequently detected in fishery products. Octyltins are not found in fishery products. Some bivalve molluscs show arsenic levels up to $15.8 \mathrm{mg} \mathrm{kg}^{-1}$. It seems that the levels of arsenic in the environment derive less from bioaccumulation, than from whether the arsenic is in an organic or inorganic form. In regard to the other metals, levels of zinc and magnesium are higher in oysters than in mussels.

To protect shellfish from chemical contamination, programs have been established to monitor water masses along coastal areas. The French monitoring network (ROCCH) focuses on environmental matrices that accumulate contaminants. These include both biota and sediment. Example contaminants were studied in a French coastal lagoon (Arcachon Bay) and in an estuary (Bay of Seine), and these were used to illustrate the usefulness of the monitoring programs. Twenty-one pesticidal and biocidal active substances were detected in the waters of Arcachon Bay during the summers from 1999 to 2003, at concentrations ranging from a few $n g \mathrm{~L}^{-1}$ to several hundred $\mathrm{ng} \mathrm{L}^{-1}$. Most of the detected substances were herbicides, including some that are now banned. Organotin compounds have been detected in similarly semi-enclosed waters elsewhere (bays, estuaries, harbors). However, the mean concentrations of cadmium, mercury, lead and benzo[a]pyrene, in transplanted mussels, were below the regulatory limits.

In 2007, the mean daily consumption of shellfish in the general French population was estimated to be $4.5 \mathrm{~g}$ in adults; however, a wide variation occurs by region and season (INCA2 study). Tabulated as a proportion of the diet, shellfish consumption represents only $0.16 \%$ of overall solid food intake. However, the INCA 2 survey was not well-suited to estimating shellfish consumption, because of the small number of shellfish consumers sampled. In contrast, the mean consumption rate of bivalve molluscs among adult high consumers of fish and seafood products, i.e., adults who eat fish or seafood at least twice a week, was estimated to be $153 \mathrm{~g}$ a week $\left(8 \mathrm{~kg} \mathrm{yr}^{-1}\right)$. The highest mean consumption is for king scallops (39 $\left.\mathrm{g} \mathrm{wk}^{-1}\right)$, followed by oysters $\left(34 \mathrm{~g} \mathrm{wk}^{-1}\right)$ and mussels $\left(22 \mathrm{~g} \mathrm{wk}^{-1}\right)$. Thus, for high seafood consumers, the contribution of shellfish to inorganic contaminant levels is 1 to $10 \%$ of TWI, or PTWI for Cd, MeHg, and Sn (up to 19\% for Sn), and the arsenic body burden is higher for $22 \%$ of individuals studied.

The human health risks associated with consuming chemical contaminants in shellfish are difficult to assess for several reasons: effects may only surface after long-term exposure (chronic risk), exposures may be discontinuous, and contamination may derive from multiple sources (food, air, occupational exposure, etc.). Therefore, it is not possible to attribute a high body burden specifically to shellfish consumption, even if seafood is a major dietary contributor of some contaminant, e.g., arsenic and mercury.

The data assembled in this review provide the arguments for maintaining the chemical contaminant monitoring programs for shellfish. Moreover, the results presented herein suggest that monitoring programs should be extended to other chemicals that are suspected of presenting a risk to consumers, as illustrated by the high level reported for arsenic (in urine) of high consumers of seafood products from the CALIPSO study. In addition, the research conducted in shellfish farming areas of Arcachon Bay highlights the need to monitor TBT and PAH contamination levels, to ensure that these chemical pollutants do not migrate from the harbor to oyster farms.

Finally, we have concluded that shellfish contamination from seawater offers a rather low risk to the general French population, because shellfish do not constitute a major contributor to dietary exposure of chemical contaminants. Notwithstanding, consumer vigilance is necessary among regular shellfish consumers, and especially for those residing in fishing communities, for pregnant and breast-feeding women and for very young children. 


\section{References}

Afssa (2004) Avis du 16 mars 2004 de l'Agence relatif à la réévaluation des risques sanitaires du méthylmercure liés à la consommation des produits de la pêche au regard de la nouvelle dose hebdomadaire tolérable provisoire (DHTP). Available from http://www.afssa.fr/Documents/RCCP2003sa0380.pdf

Afssa (2005) Rapport sur «Dioxines, furanes et PCB de type dioxines: Evaluation de l'exposition de la population française », Novembre 2005, 57 pages. Available from http://www.afssa.fr/Documents/RCCP2005sa0372.pdff

Afssa (2006) Avis du 18 avril 2006 sur l'évaluation des risques liés à la présence d'organoétains dans les aliments. Available from http://www.afssa.fr/Documents/RCCP2005sa0091.pdf

Afssa (2007a) Avis du 26 juillet 2007 sur la mise en place de règles hygièniques d'utilisation de l'eau de mer propre pour la manipulation des produits de la mer. Available from http://www.afssa.fr/Documents/RCCP2006sa0314.pdf

Afssa (2007b) Avis du 31 octobre 2007 sur la pertinence d'établir une teneur maximale en cadmium pour les gastéropodes, les échinodermes et les tuniciers et à l'évaluation des risques sanitaires liés à des teneurs élevées en cadmium dans les bulots et les pétoncles. Available from http://www.afssa.fr/Documents/RCCP2007sa0098.pdf

Afssa (2008a) Avis du 21 Mars 2008 relatif à l'évaluation du dispositif de surveillance du milieu et à l'évaluation du risque lié à la consommation des coquillages, notamment dans la situation du bassin d'Arcachon. Available from http://www.afssa.fr/Documents/RCCP2006sa0254b.pdf

Afssa (2008b) Rapport sur l'Evaluation de la surveillance chimique des zones de production conchylicole du risque lié à la consommation des coquillages, notamment dans la situation du bassin d'Arcachon. Available from http://www.afssa.fr/Documents/RCCP2006sa0254bRa.pdf

Afssa (2008c) Avis du 16 septembre 2008 sur la pertinence des outils de détection des phycotoxines lipophiles dans les coquillages. Available from http://www.anses.fr/cgibin/countdocs.cgi?Documents/RCCP2008sa0268.pdf

Alzieu C, Michel P, Tolosa I, Bacci E, Mee LD, Readman JW (1991) Organotin compounds in the Mediterranean: A continuing cause for concern. Mar Environ Res 32:261-270.

Amiard JC (1991) Réponses des organismes marins aux pollutions métalliques. In: CNRS (ed). Réactions des êtres vivants aux changements de l'environnement. Actes des Journées de l'Environnement du CNRS, Paris, p 197-205.

Amiard JC, Berthet B (1996) Fluctuations of cadmium, copper, lead and zinc concentrations in field populations of the Pacific oyster Crassostrea gigas in the bay of Bourgneuf (Atlantic coast, France). Ann Inst Oceanogr 72:195-207.

Amiard JC, Amiard-Triquet C, Berthet B, Metayer C (1986) Contribution to the ecotoxicological study of $\mathrm{Cd}, \mathrm{Pb}, \mathrm{Cu}$ and $\mathrm{Zn}$ in the mussel Mytilus edulis. 1 - Field study. Mar Biol 90:425-431.

Amiard JC, Amiard-Triquet C, Berthet B, Metayer C (1987) Comparative study of the patterns of bioaccumulation of essential $(\mathrm{Cu}, \mathrm{Zn})$ and non-essentiel $(\mathrm{Cd}, \mathrm{Pb})$ trace metals in various estuarine and costal organisms. J Exp Mar Biol Ecol 106:73-89.

Amiard JC, Amiard-Triquet C, Barka S, Pellerin J, Rainbow PS (2006) Metallothioneins in aquatic invertebrates: their role in metal detoxification and their use as biomarkers. Aquat Toxicol 76: 160-202.

Amiard JC, Amiard-Triquet C, Charbonnier L, Mesnil A, Rainbow PS, Wang WX (2008) Bioaccessibility of essential and no-essential metals in commerciel shellfish from Western Europe and Asia. Food Chem Toxicol 46:2010-2022.

Amiard-Triquet C, Amiard JC (1980). Radioécologe des milieux aquatiques. Masson, Paris, $191 \mathrm{p}$.

Andral B, Stanisiere JY, Sauzade D, Damier E, Thebault H, Galgani F, Boissery P (2004) Monitoring chemical contamination levels in the Mediterranean based on the use of mussel caging. Mar Pollut Bull 49:704-712. 
Apeti DA, Lauenstein GG, Christensen JD, Kimbrough K, Johnson WE, Kennedy M, Grant KG (2010) A historical assessment of coastal contamination in Birch Harbor, Maine based on the analysis of mussels collected in the 1940s and the Mussel Watch Program. Mar Pollut Bull 60:732-742.

ATSDR (2007) ToxGuide for Arsenic. cas\#7440-38-2. http://www.atsdr.cdc.gov/toxguides/toxguide-2.pdf?id=21\&tid=3

Auby I, Maurer D (2004) Etude de la reproduction des huîtres creuses dans le bassin d'Arcachon.Ifremer Edition, Nantes, 327 p.

Averty B, Michel P, Chiffoleau JF (2005) Les composés organostanniques dans les mollusques du littoral français. RNO, 2005. Ifremer editor, Nantes, p35-38.

Bard SM (2000) Multixenobiotic resitance as a cellular defense mechanism in aquatic organisms. Aquat Toxicol 48:357-389.

Berthet B (2008) Les espèces sentinelles. In : Les biomarqueurs dans l'évaluation de l'état écologique des milieux aquatiques. Amiard J-C, Amiard-Triquet C (eds) Lavoisier, Tec\&Doc, Paris, 121-148.

Borak J, Hosgood D (2007) Seafood arsenic: implications for human risk assessment. Regul Toxicol Pharmacol 47:204-212.

Bryan GW (1976) Heavy metal contamination in the sea. In: Johnston R (ed) Marine Pollution. Academic Press, London and New York, p 185-302.

Bryan GW, Langston WJ, Humerstone LG, Burt GR, Ho YB (1983) An assessment of the gastropod Littorine littorea as an indicator of heavy-metal contamination in United kingdom estuaries. J mar Biol Ass 63:327-345.

Buchet JP, Lison D, Ruggeri M, Foa V, Elia G (1996) Assessment of exposure to inorganic arsenic, a human carcinogen, due to the consumption of seafood. Arch Toxicol 70:773-778.

Bügel SH, Sandström B, Larsen EH (2001) Absorption and retention of selenium from shrimps in man. J Trace Elem Med Biol 14:198-204.

Butler PA (1973) Residues in fish, wildlife, and estuaries; organochlorine residues in estuarine molluscs, 1965- 1972. National Pesticides Monitoring Program. J Pestic Monit 6:238-362.

Cannon JR, Saunders JB, Toia RF (1983) Isolation and preliminary toxicological evaluation of arsenobetaine - the water soluble arsenical constituent from the hepatopancreas of the western rock lobster. Sci Tot Environ 31:181-185.

Cantillo AY (1998) Comparison of results of mussel watch programs of the United States and France with worldwide mussel watch studies. Mar Pollut Bull 36:712-717.

Casas S, Bacher C (2006) Modelling trace metal $(\mathrm{Hg}$ and $\mathrm{Pb}$ ) bioaccumulation in the Mediterranean mussel, Mytilus galloprovincialis, applied to environmental monitoring. J Sea Res 56:168-181.

Chiffoleau J-F, Auger D, Chertier E, Le Goff R, Justome V, Maheux F, Pierre-Duplessis O, Etourneau C (2002) Variabilité de la contamination des Bulots et Coquilles Saint Jacques en Baie de Seine par les métaux. Rapport Scientifique du programme Seine-Aval, Phase 2

Chong K, Wang WX (2001) Comparative studies on the biokinetics of $\mathrm{Cd}$, Cr, and $\mathrm{Zn}$ in the green mussel Perna viridis and the Manila clam Ruditapes philippinarum. Environ Pollut 115:107-121.

Claisse $D$ (1989) Chemical contamination of French coasts: the results of a ten years mussel watch. Mar Pollut Bull 20:523-528.

Claisse D (1992) Accumulation des métaux lourds et polluants organiques par les coquillages. In: Lesne J., editor. Coquillages et santé publique. Du risque à la prévention. ENSP. p 99-111.

Claisse D (1999) Le RNO : Programmes actuels. Surveillance du Milieu Marin. Travaux du réseau national d'observation de la qualité du milieu marin: Bulletin RNO Edition 1999. p 5-10.

Claisse D, Alzieu C (1993) Copper contamination as a result of antifouling paint regulations ? Mar Pollut Bull 26:395-397. 
Claisse D, Le Moigne M, Durand G, Beliaeff B (2006) Ligne de base : les contaminants chimiques dans les huîtres et les moules du littoral français. Surveillance du Milieu Marin. Travaux du réseau national d'observation de la qualité du milieu marin: Bulletin RNO Edition 2006. p 27-51.

Claisse D, Cossa D, Bretaudeau-Sanjuan J, Touchard G, Bombled B (2001) Methylmercury in molluscs along the French coast. Mar Pollut Bull 42:329-332.

CNC (2010) http://www.cnc-france.com/index.php?rub=2

Crecelius EA (1977). Changes in the chemical speciation of arsenic following ingestion by man. Environ Health Perspect 19:47-50.

De Kock WC, Kramer KJM (1994) Active biomonitoring (ABM) by translocation of bivalve molluscs. In: Kramer KJM, editor. Biomonitoring of coastal waters and estuarines. CRC Press, Boca raton, $\mathrm{p}$ 51-84.

Devier MH, Augagneur S, Budzinski H, Le Menach K, Mora P, Narbonne JF, Garrigues P (2005) One-year monitoring survey of organic compounds (PAHs, PCBs, TBT), heavy metals and biomarkers in blue mussels from the Arcachon bay, France. J Environ Monit 7:224-240.

EAT (2004) Etude de l'alimentation totale française. Mycotoxines, minéraux et éléments traces. Leblanc JC (coord.) Verger P, Guérin T, Volatier JL (INRA/DGAL, Mai 2004, 68 pages)

EEC (1991) Directive (EEC) No 492/1991 of 15 July 1991 laying down the health conditions for the production and the placing on the market of live bivlave molluscs. $19 p$

EC (2000) Directive (EC) No 60/2000 of the European parliament and of the council of 23 October 2000 establishing a framework for Community action in the field of water policy. Official Journal of the European Communities, L327/1-72

EC (2001) Regulation (EC) $N^{\circ} 466 / 2001$ of the European parliament and the council of 8 March 2001 setting maximum levels for certain contaminants in foodstuffs. Official Journal of the European Communities, L77/1-13.

EC (2004a) Regulation (EC) No 853/2004 of the European parliament and the council of 29 April 2004 laying down specific hygiene rules for food of animal origin. Official Journal of the European Communities, L226/22-82.

EC (2004b) Regulation (EC) No 852/2004 of the European parliament and the council of 25 June 2004 on the hygiene of foodstuffs. Official Journal of the European Communities, L226/3-21.

EC (2004c) Regulation (EC) No 854/2004 of the European parliament and the council of 25 June 2004 laying down specific rules for the organisation of official controls on products of animal origin intended for human consumption. Official Journal of the European Communities, L226/83-127.

EC (2006a) Regulation (EC) No 776/2006 of the European parliament and the council of 23 May 2006 amending Annex VII to Regulation (EC) No 882/2004 of the European Parliament and of the Council as regards Community reference laboratories. Official Journal of the European Communities, L136/3-8

EC (2006b) Regulation (EC) No 882/2006 of the European parliament and the council of 16 June 2006 concerning tenders notified in response to the invitation to tender for the export of common wheat issued in Regulation (EC) No 1059/2005. Official Journal of the European Communities, L164/24-26

EC (2006c) Regulation (EC) No 1881/2006 of the European parliament and the council of 19 December 2006 setting maximum levels for certain contaminants in foodstuffs. Official Journal of the European Communities, L364/5-22.

EC (2008a) Regulation (EC) No 629/2008 of the European parliament and the council of 2 July 2008 amending Regulation (EC) No 1881/2006 setting maximum levels for certain contaminants in foodstuffs. Official Journal of the European Communities, L173/6-9.

EC (2008b) Directive (EC) No 105/2008 of the European parliament and of the council of 16 December 2008 on environmental quality standards in the field of water policy. Official Journal of the European Communities, L348/84-97 
EFSA (2004a) Opinion of the Scientific Panel on Contaminants in the food chain on a request from the commission related to mercury and methylmercury in food. EFSA Journal 34:1-14.

EFSA (2004b) Opinion of the Scientific Panel on Contaminants in the food chain on a request fromthe commission to assess the health risks to consumers associated with exposure to organotins in foodstuffs. EFSA Journal 102:1-119.

EFSA (2009) Scientific Opinion on Cadmium in Food. EFSA Panel on Contaminants in the Food Chain (CONTAM). EFSA Journal 980:1-139.

EFSA (2010) Scientific Opinion on Lead in Food. EFSA Journal 8(4):1570

England GC, McGrath TP, Gilmer L, Seebold JG, Lev-On M, Hunt T (2001) Hazardous air pollutant emissions from gas-fired combustion sources: emissions and the effects of design and fuel type. Chemosphere 42:745-764.

Ettajani H, Amiard-Triquet C, Jeantet AY, Amiard JC, Ballan-Dufrançais C (1996) Fate and effects of soluble or sediment-bound arsenic in oysters (Crassostrea gigas Thun.). Arch Environ Contam Toxicol 31:38-46.

Fatta-Kassinos D, Meric S, Nikolaou A (2011) Pharmaceutical residues in environmental waters and wastewater: current state of knowledge and future research. Anal Bioanal Chem 399: 251-275.

Foa V, Colombi A, Maroni M, Buratti M, Calzaferri G (1984) The speciation of the chemical forms of arsenic in the biological monitoring of exposure to inorganic arsenic. Sci tot Environ 34:241-259.

Francesconi KA, Edmonds JS (1998) Arsenic species in marine samples. Croat Chem Acta 71:343-359.

Francesconi KA, Tangaar R, Mc Kenzie CJ, Goessler W (2002) Arsenic metabolites in human urine after ingestion of an arsenosugar. Clin Chem 48:92-101.

Franco J, Borja Á, Solaun O, Pérez V (2002) Heavy metals in molluscs from the Basque Coast (Northern Spain): results from an 11-year monitoring programme. Mar Pollut Bull 44:973-976.

Freeman HC, Uthe JF, Fleming RB, Odense PH, Ackman RG, Landry G, Musial C (1979) Clearance of arsenic ingested by man from arsenic contaminated fish. Bull Environ Contam Toxicol 22:224-229.

Gagnaire B, Thomas-Guyon H, Burgeot T, Renault T (2006) Pollutant effects on Pacific oyster, Crassostrea gigas (Thunberg), hemocytes: Screening of 23 molecules using flow cytometry. Cell Biol Toxicol 22:1-14.

Geffard A, Amiard JC, Amiard-Triquet C (2002) Kinetics of metal elimination in oysters from a contaminated estuary. Comp Biochem Physiol C: Toxicol Pharmacol 131:281-293.

George SG, Pirie BJ, Frazier JM, Thomson JD (1984) Interspecies differences in heavy metal detoxication in oysters. Mar Environ Res 14:462-464.

George SG, Pirie, BJS, Cheyne AR, Coombs TL, Grant PT (1978) Detoxication of metals by marine bivalves: an ultrastructural study of the compartmentation of copper and zinc in the oyster, Ostrea edulis. Mar Biol 45: 147-156.

Goldberg ED (1975) The mussel watch - A first step in global marine monitoring. Mar Pollution Bull 6:111-113.

Goldberg ED, Koide M, Hodge V, Flegal AR, Martin J (1983) U.S. Mussel Watch: 1977-1978 results on trace metals and radionuclides. Estuarine, Coastal Shelf Sci 16:69-93.

Goldberg ED, Bowen VT, Farrington JW, Harvey G, Martin JH, Parker PL, Risebrough RW, Robertson W, Schneider E, Gamble E (1978) The mussel watch. Environmental conservation 5: 101-125

Gomez-Ariza JL, Morales E, Giraldez I (1999) Uptake and elimination of tributyltin in clams, Venerupis decussata. Mar Environ Res 47:399-413.

Guerin T, Sirot V, Volatier JL, Leblanc JC (2007) Organotin levels in seafood and its implications for health risk in high-seafood consumers. Sci Total Environ 388: 66-77

Hamilton SJ (2004) Review of selenium toxicity in the aquatic food chain. Sci Total Environ 326:1-31.

Han BC, Jeng WL, Tsai YN, Jeng MS (1993) Depuration of copper and zinc by green oysters and blue mussels of Taiwan. Environ Pollut 82:93-97. 
He M, Ke CH, Wang WX (2010) Effects of cooking and subcellular distribution on the bioaccessibility of trace elements in two marine fish species. J Agric Food Chem 58:3517-3523.

Hédouin L, Pringault O, Metian M, Bustamante P, Warnau M (2007) Nickel bioaccumulation in bivalves from the New Caledonia lagoon: Seawater and food exposure. Chemosphere 66:1449-1457.

Heinrich-Ramm R, Mindt-Prüfert S, Szadkowski D (2002) Arsenic species excretion after controlled seafood consumption. J Chromatogr B 778:263-273.

Heinzow B, Mohr S, Ostendorp G, Kerst M, Körner W (2007) PCB and dioxin-like PCB in indoor air of public buildings contaminated with different $P C B$ sources - deriving toxicity equivalent concentrations from standard PCB congeners. Chemosphere 67:1746-1753.

Hillwalker WE, Jepson PC, Anderson KA (2006) Selenium accumulation patterns in lotic and lentic aquatic systems. Sci Total Environ 366:367-379.

Hori T, Nakagawa R, Tobiishi K, Lida T, Tsutumi T, Sasaki K, Toyoda M (2005) Effects of cooking on concerns of polichlorinated dibenzo-p-dioxins and related coumpounds in fish and meat. J Agric Food Chem 53:8820-8828.

Hsueh YM, Hsu MK, Chiou HY, Yang MH, Huang CC, Chen CJ (2002) Urinary arsenic speciation in subjects with or without restriction from seafood dietary intake. Toxicol Lett 133:83-91.

Huet M, Michel P, Averty B, Paulet YM (2003) Imposex-TBT. La pollustion par les organostanniques le long des côtes françaises, de la Manche et de l'Atlantique. Réseau national d'obersvations. 133p.

INCA 1 (1999) Enquête individuelle et nationale sur la consommation alimentaire. Report. http://www.afssa.fr/index.htm

INCA 2 (2009) Enquête individuelle et nationale des consommations alimentaires 2 (INCA 2) 2006-2007. Report 228 p. http://www.afssa.fr/index.htm

Ineris (2010) http://www.ineris.fr/index.php

INRS (2010) http://www.inrs.fr/inrs-pub/inrs01.nsf/IntranetObject-accesParReference/INRSFR/\$FILE/fset.html.

IRSN (2010) http://www.irsn.fr/FR/Pages/home.aspx.

James A, Claisse D, Marchand M (2006) Les normes de qualité environnementales (NQE), outils d'évaluation du bon état chimique. In: Ifremer, editor. RNO, Surveillance du Milieu Marin. Nantes. p 20-26.

International chemical safety sheets http://training.itcilo.it/actrav_cdrom2/fr/osh/ic/alfamain.htm

JEFCA (2001) Summary of the $57^{\text {th }}$ meeting of the joint FAO/WHO expert committee on food additives. Rome, 5-14 June 2001.

JECFA (2010a) Joint FAO/WHO expert committee on food additives seventy-second meeting Rome, 16-25 February 2010 summary and conclusion. Issued 16th March 2010, 1-16.

JECFA (2010b) Joint FAO/WHO expert committee on food additives seventy-third meeting Geneva, 8-17 June 2010 summary and conclusion. Issued 24th June 2010, 1-17.

Johnson MA, Paulet YM, Donval A, Le Pennec M (1996) Histology, histochemistry and enzyme biochemistry in the digestive system of the endosymbiont-bearing bivalve Loripes lucinalis (Lamarck). J Exp Mar Biol Ecol 197:15-38.

JORF (1999) Arrêté du 21 mai 1999 relatif au classement de salubrité et à la surveillance des zones de production et des zones de reparcage des coquillages vivants. 85088509.

Kaise T, Watanabe S, Itoh K (1985) The acute toxicity of arsenobetaine. Chemosphere 14:1327-1332.

Kales SN, Huyck KL, Goldman RH (2006) Elevated urine arsenic: un-speciated results lead to unnecessary concern and further evaluations. J Anal Toxicol 30:80-85.

Langston WJ (1983) The behaviour of arsenic in selected U.K. estuaries. Can J Fish Aquat Sci 40:143-150. 
Leblanc JC, Volatier JL, Sirot V, Bemrah-Aouchia N (2006) CALIPSO : Fish and seafood consumption study and biomarker of exposure to trace elements, pollutants and omega

3. Report, 162 p. http://www.afssa.fr/Documents/PASER-Ra-Calipso.pdf

Leblanc JC, Guérin T, Noël L, Calamassi-Tran G, Volatier JL, Verger P (2005) Dietary exposure estimates of 18 elements from the 1st French Total Diet Study. Food Add Contam: Part A 22:624 - 641.

Lewtas J (2007) Air pollution combustion emissions: Characterization of causative agents and mechanisms associated with cancer, reproductive, and cardiovascular effects. Mutation Res 636:95-133.

Liber K, Culp JM, Kerrich R (2006) Importance de la spéciation de l'arsenic pour exprimer la toxicité de cet élément dans les organismes aquatiques: implications pour les recommandations pour la qualité des eaux du Canada. Santé Canada.

Lim PE, Lee CK, Din Z (1998) The kinetics of bioaccumulation of zinc, copper, lead and cadmium by oysters (Crassostrea iredalei and $C$. belcheri) under tropical field conditions. Sci Total Environ 216:147-157.

Lorenzana RM, Yeow AY, Colman JT, Chappell LL, Choudhury H (2009) Arsenic in Seafood. Hum Ecol Risk Assess, 15: 185-200.

Ma M, Le XC (1998) Effect of arsenosugar ingestion on urinary arsenic speciation. Clin Chem 44:539-550.

Manta DS, Angelone M, Bellanca A, Neri R, Sprovieri M (2002) Heavy metals in urban soils: a case study from the city of Palermo (Sicily), Italy. Sci Total Environ 300:229-243.

Martoja R, Ballan-Dufrançais C, Jeantet AY, Gouzerth P, Amiard JC, Amiard-Triquet C, Berthet B, Baud JP (1988) Effets chimiques et cytologiques de la contamination expérimentale de l'huître Crassotrea gigas Thunberg par l'argent administré sous forme dissoute et par voie alimentaire. Can J Fish Aquat Sci 44:539-550.

Merian E, Anke M, Ihnat M, Stoeppler M (2004) Elements and their compounds in the environment Wiley-VCH, Weinheim.

Metian M, Charbonnier L, Oberhaënsli F, Bustamante P, Jeffree R, Amiard JC, Warnau M. (2009) Assessment of metal, metalloid, and radionuclide bioaccessibility from mussels to human consumers, using centrifugation and simulated digestion methods coupled with radiotracer techniques. Ecotoxicol Environ Safety 72:1499-1502.

Michel P (1993) L'arsenic en milieu marin. Biogéochimie et écotoxicologie. Repères Océan $\mathrm{n}^{\circ} 4$ : Ifremer Edition. $62 \mathrm{p}$.

Michel P, Averty B (1999) Contamination of French Coastal Waters by Organotin Compounds: 1997 Update. Mar Pollut Bull 38:268-275.

Miramand P, Guary JC, Fowler SW (1980) Vanadium transfer in the mussel Mytilus galloprovincialis. Mar Biol 56:281-293.

Mozaffarian DMD, Rimm EB (2006) Fish intake, contaminants, and human health. Evaluating the risks and the benefits. JAMA 296:1885-1899.

Mourgaud Y, Martinez E, Geffard A, Andral B, Stanisiere JY, Amiard JC (2002) Metallothionein concentration in the mussel Mytilus galloprovincialis as abiomarker of response to metal contamination: validation in the field. Biomarkers 7:479-490.

Munoz O, Devesa V, Suner MA, Velez D, Montoro R, Urieta I, Macho ML, Jalon M (2000) Total and inorganic arsenic in fresh and processed fish products. J Agric Food Chem 48:4369-4376.

Murray AP, Richardson BJ, Gibbs CF (1991) Bioconcentration factors for petroleum hydrocarbons, PAHs, LABs and biogenic hydrocarbons in the blue mussel. Mar Pollut Bull 22:595-603.

Nakagawa R, Yumita Y, Hiromoto M (1997) Total mercury intake from fish and shellfish by Japanese people. Chemosphere 35:2909-2913.

Narbonne JF, Michel X (1997) Systèmes de biotransformation chez les mollusques aquatiques. In: Lagadic L, Caquet T, Amiard JC, Ramade F, editors. Biomarqueurs en écotoxicologie. Aspects fondamentaux Paris: Masson. p 11-31. 
Noël L, Leblanc JC, Guérin T (2003) Determination of several elements in duplicate meals from catering establishment using closed vessel microwave digestion with inductively coupled plasma mass spectrometry detection: estimation of daily dietary intake. Food Addit Contam 20: 44-56.

Noël L, Testu C, Chafey C, Velge P, Guérin T (2011) Contamination levels for lead, cadmium and mercury in marine gastropods, echinoderms and tunicates. Food Control 22, 433437

Noël L, Testu C, Chafey C, Pinte J, Velge P, Guérin T (In Press ) Contamination levels for lead, cadmium and mercury in big crustaceans: differences between white and brown meats. J Food Compos Anal

O'Connor TP (1998) Mussel watch results from 1986 to 1996. Mar Pollut Bull 37:14-19.

OSPAR (2007) Second periodic evaluation of progress towards the objective of the OSPAR radioactive substances strategy (JAMP product RA-2)

OSPAR (2008) The convention for the protection of the marine environment of the NorthEast Atlantic; 2007/2008 CEMP Assessment: Trends and concentration of selected hazardous substances in sediments and trends in TBT-specific biological effects. Available from http://www.ospar.org/documents/dbase/publications/p00378 20072008 CEMP assessment.pdf

Page DS, Dassanayake TM, Gilfillan ES (1995) Tissue distribution and depuration of tributyltin for field-exposed Mytilus edulis. Marine Environmental Research 40:409421.

Pain S, Parant M (2003) Multixenobiotic defence mechanism (MXDM) in bivalves. Comptes Rendus Biologies 326:659-672.

Pilliére F, Conso F (2007) Biotox. Guide biotechnologique pour les médecins du travail. INRS.

Polikarpov GG (1960) Absorption of short-lived radioactivity by sea organisms. Priroda 49:105-7.

Pradel J, Zettwoog P, Dellero N, Beutier D (2001) Le polonium 210, un repère naturel important en radioprotection. Radioprotection 36:401-416.

Pruell RJ, Lake JL, Davis WR, Quinn JG (1986) Uptake and depuration of organic contaminants by blue mussels (Mytilus edulis) exposed to environmentally contaminated sediment. Mar Biol 91:497-507.

Roux N, Chiffoleau JF, Claisse D (2001) L'argent, le cobalt, le nickel et le vanadium dans les mollusques du littoral français. Surveillance du milieu marin. In: Ifremer, editor. Travaux RNO, 2001. p 11-20.

Richardson SD, Ternes TA (2005) Water analysis: Emerging contaminants and current issues. Anal Chem 77: 3807-3838

Saavedra Y, Fernández P, González A (2004) Determination of vanadium in mussels by electrothermal atomic absorption spectrometry without chemical modifiers. Anal. Bioanal.Chem 379:72-76.

Sabbioni E, Fischbach M, Pozzi G, Pietra R, Gallorini M, Piette JL (1991) Cellular retention toxicity and carcinogenic potential of seafood arsenic. I. Lack of cytotoxicity and fransforming activity of arsenobetaine in the BALB/3T3 cell line. Carcinogenesis 12:1287-1291.

Samain JF, McCombie H (2008) Summer mortality of Pacific oyster Crassostrea gigas - The MOREST projet.

Sanders JG, Osman RW, Riedel GF (1989) Pathways of arsenic uptake and incorporation in estuarine phytoplankton and the filter-feeding invertebrates Eurytemora affinis, Balanus improvisus and Crassostrea virginica. Mar Biol 103:319-325.

Sauvage C, Pépen JF, Lapégue S, Boudry P, Renault T (2009) Ostreid herpes virus 1 infection in families of the Pacific oyster, Crassostrea gigas, during a summer mortality outbreak: Differences in viral DNA detection and quantification using realtime PCR. Virus Res 142:181-187. 
Schaffner M, Bader HP, Scheidegger R (2009) Modeling the contribution of point sources and non-point sources to Thachin River water pollution. Sci Total Environ 407:49024915.

Schoof RA, Yager JW (2007) Variation of Total and Speciated Arsenic in Commonly Consumed Fish and Seafood. Hum Ecol Risk Assess, 13: 946-965.

Schoof RA, Yost LJ, Eickhoff J, Crecelius EA, Cragin DW, Meacher DM, Menzel DB (1999) A Market Basket Survey of Inorganic Arsenic in Food. Food Chem Toxicol 37:839-846.

SCOOP (2004) Report on tasks 3.2.11. Assessment of the dietary exposure to arsenic, cadmium, lead and mercury of the population of the EU Members States, 1-125. Avalaible at http://ec.europa.eu/food/food/chemicalsafety/contaminants/scoop_3-211_heavy_metals_report_en.pdf

Sericano JL, Wade TL, Brooks JM (1996) Accumulation and depuration of organic contaminants by the American oyster (Crassostrea virginica). Sci Total Environ 179:149-160.

Sharma VK, Sohn M (2009) Aquatic arsenic: Toxicity, speciation, transformations, and remediation. Environ Int 35:743-759.

Sirot V, Guérin T, Mauras Y, Garraud H, Volatier JL, Leblanc JC (2008) Methylmercury exposure assessment using dietary and biomarker data among frequent seafood consumers in France. Environ Res 107:30-38.

Sirot V, Guérin T, Volatier J, Leblanc JC (2009) Dietary exposure and biomarkers of arsenic in consumers of fish and shellfish from France. Sci Total Environ 407:1875-1885.

Soto M, Cajaraville MP, Marigómez I (1996) Tissue and cell distribution of copper, zinc and cadmium in the mussel, Mytilus galloprovincialis, determined by autometallography. Tissue and Cell 28:557-568.

Storelli MM, Ceci E, Marcotrigiano GO (1998) Comparison of Total Mercury, Methylmercury, and Selenium in Muscle Tissues and in the Liver of Stenella coeruleoalba (Meyen) and Caretta caretta (Linnaeus). Bull Environ Contamin Toxicol 61:541-547.

Sukasem P, Tabucanon MS (1993) Monitoring heavy metals in the Gulf of Thailand using mussel watch approach. Sci Total Environ 139-140:297-305.

SU-VI-MAX (2002) Portions alimentaires: manuel photos pour l'estimation des quantités, editor Polytechnica, Paris

Tripp BW, Farrington JW, Goldberg ED, Sericano J (1992) International Mussel Watch: the initial implementation phase. Mar Pollut Bull 24:371-373.

Van Caneghem J, Block C, Van Brecht A, Wauters G, Vandecasteele C (2010) Mass balance for POPs in hazardous and municipal solid waste incinerators. Chemosphere 78:701-708.

Vos G, Hovens JPC, Hagel P (1986) Chromium, nickel, copper, zinc, arsenic, selenium, cadmium, mercury and lead in Dutch fishery products 1977-1984. Sci Total Environ 52:25-40.

Walraven N, Laane RW (2009) Assessing the discharge of pharmaceuticals along the Dutch coast of the North Sea. Rev Environ Contam Toxicol 199: 1-18.

Wei C, Li W, Zhang C, Van Hulle M, Cornelis R, Zhang X (2003) Safety evaluation of organoarsenical species in edible porphyra from the China Sea. J Agric Food Chem 51:5176-5182.

Yang RQ, Zhou QF, Jiang GB. (2006) Butyltin accumulation in the marine clam Mya arenaria: An evaluation of its suitability for monitoring butyltin pollution. Chemosphere 63:1-8. 
Fig. 1 Distribution of contamination in mussels and oysters in French shellfish farming areas from 2003 to 2007 (data from Claisse et al. 2006 for 2003 to 2005; unpublished results from the same authors for 2006 to 2007 period). (A) Cadmium (B) Lead (C) Mercury in mg kg-1 fresh wt, and (D) benzo[a]pyrene in $\mu \mathrm{g} \mathrm{kg-1}$ fresh wt (E) provides values used to construct graphs $A$ to $D$
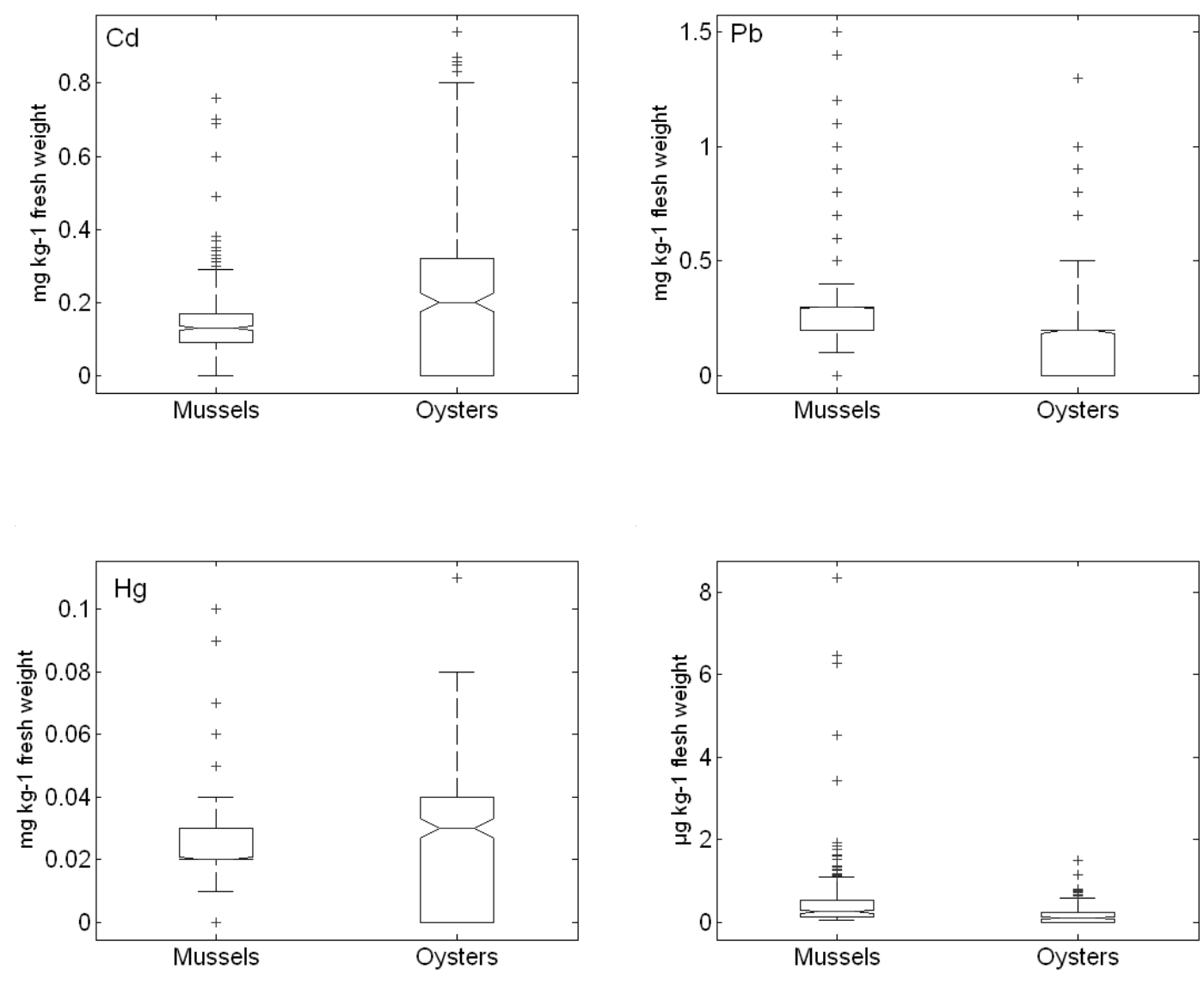

\begin{tabular}{ccc}
\hline $\mathbf{E}$ & Mussels & Oysters \\
\hline Cadmium & $0.15 \pm 0.09(\mathrm{n}=374)$ & $0.34 \pm 0.18(\mathrm{n}=239)$ \\
Lead & $0.03 \pm 0.01(\mathrm{n}=374)$ & $0.04 \pm 0.02(\mathrm{n}=239)$ \\
Mercury & $0.03 \pm 0.02(\mathrm{n}=374)$ & $0.03 \pm 0.02(\mathrm{n}=239)$ \\
Benzo[a]pyrene & $0.56 \pm 1.01(\mathrm{n}=180)$ & $0.27 \pm 0.24(\mathrm{n}=180)$ \\
\hline
\end{tabular}




\section{Tables}

Table 1 : List of Abbreviations and Acronyms Used in this Review

AFSSA: Agence Française de Sécurité Sanitaire des Aliments (French food safety agency) (website : www.anses.fr)

ANSES: Agence Nationale de Sécurité Sanitaire de l'alimentation, de l'environnement et du travail (French agency for food, environmental and occupational health \& safety) (website : www.anses.fr)

ATSDR: Agency for Toxic Substances and Disease Registry

BCF: Bioconcentration factors

BWT: Body weight

$\mathrm{BMDL}_{01}$ : Benchmark Dose (Lower Confidence Limit 0.01)

$\mathrm{BMDL}_{05}$ : Benchmark Dose (Lower Confidence Limit 0.05)

BQSPMED: Bureau de la Qualité Sanitaire des Produits de la Mer et d'Eau Douce (Office for the quality and safety of food products from fresh and marine waters)

BRAB: Bureau de la Réglementation Alimentaire et des Biotechnologies (Office of Food and Biotechnology Regulations)

BTEX: Benzene, Toluene, Ethylbenzene, Xylene

CALIPSO: Etude des Consommations ALimentaires de produits de la mer et Imprégnation aux éléments traces, PolluantS and Omega-3 (Fish and seafood consumption study and biomarker of exposure to trace elements, pollutants and omega-3)

CF: concentration factor

CNC: French national shellfish farming committee

DBT: dibutyltin

DDAM: Direction Départementale des Affaires Maritimes ( Local maritime affair authorities)

DDT: dichlorodiphenyl trichloroethane

DDE: dichlorodiphenydichloroethylene

DDD: dichlorodiphenyldichloroethane

DDSV: Direction Départementale des Services Vétérinaires (Local veterinary authorities)

DEHP: di(2-ethylhexyl)phthalate

DGAL: Direction Générale pour l'Alimentation (French directorate for food)

DGS: Direction Générale de la Santé (French directorate general for health)

DMA: dimethylarsinic acid

DOT: di-octyltin

DPMA: Direction des Pêches Maritimes et de l'Aquaculture ( Directorate for marine fisheries and aquaculture)

DPT: diphenyltin

EAT: Etudes Alimentaires Totales (Total Diet Study (TDS))

EC: European Community

EEC: European Economic Community

EFSA: European Food Safety Authority

EPA: Environmental Protection Agency

EU-RL: EU reference laboratory

FAO: Food and Agriculture Organization of the United Nations

GST: glutathione S-transferase

HACCP: Hazard Analysis Critical Control Point

IAEA: International Atomic Energy Agency

IARC: International Agency for Research on Cancer

IFREMER: Institut Français de Recherche pour l'Exploitation de la MER (French research institute for exploitation of the sea)

INCA: Enquête Individuelle et Nationale sur la Consommation Alimentaire ( Consumption data for the general population) 
INRS: Institut National de Recherche et de Sécurité (National institute of research and safety)

IRSN: Institut de radioprotection et de sûreté nucléaire (French Institute for Radiation Protection and Nuclear Safety)

JECFA: Joint FAO/WHO Expert Committee on Food Additives

JORF: Journal Officiel de la république Française (Official Journal of the French Republic

$\mathrm{LD}_{50}$ : Lethal Dose $50 \%$

LERQAP: Laboratoire d'Etudes et de Recherches sur la Qualité des Aliments et les Procédés Agroalimentaires (Laboratory of studies and research on food quality and food processes)

MAP: Mediterranean Action Plan

MCSI : Mission de Coordination Sanitaire Internationale (International health and safety coordination mission)

MeHg: methyl mercury

MED POL: Barcelona convention for the protection of the Mediterranean sea against pollution

MBT: monobutyltin

MMA: monomethylarsonic acid

MOREST: Mortalité ESTivale d'Huîtres (Oyster summer mortality program)

MPT: monophenyl tin

MT: metallothioneins

NPE: nonylphenol ethoxylates

NRL: National Reference Laboratory

OCA-EN: Observatoire des Consommations Alimentaires- Epidemiologique Nutritionnelle (Food consumption and nutritional epidemiology unit)

OPE : octyphenol ethoxylate

OSPAR: Convention for the protection of the marine environment of the North-East Atlantic P95 : $95^{\text {th }}$ percentile

PAH: Polycyclic aromatic hydrocarbon

PCB: Polychlorinated biphenyls

PCBi: indicator PCBs (sum of selected PCBs)

dl-PCB: PCB dioxin like

PCDD/Fs: polychlorinated dibenzo-dioxins/furans

PTMI: Provisional Tolerable Monthly Intake

PTWI: Provisional Tolerable Weekly Intake

REPAMO: Réseau de Pathologie des Mollusques - Mollusc pathology network

RNO: Réseau National d'Observation - French national monitoring network

$\mathrm{ROCCH}$ : Réseau d'Observation de la Contamination CHimique du milieu marin (French national monitoring network)

SCOOP: Scientific COOPeration

TBT: tribultytin

TDI: Tolerable Daily Intake

THg: total mercury

TPT: triphenyl tin

TWI: Tolerable Weekly Intake

UNEP: United Nations Environment Programme

WFD: Water Framework Directive

WHO: World Health Organization

WT: Weight 
Table 2 Regulatory thresholds for consumption of various contaminants in bivalve molluscs (EC 2006c, amended by EC 2008a)

\begin{tabular}{|l|l|r|}
\hline \multicolumn{2}{|c|}{ Contaminant } & \multicolumn{1}{c|}{$\begin{array}{l}\text { Maximum level } \\
\text { (fresh wt) }\end{array}$} \\
\hline \multirow{3}{*}{ Metals } & Lead & $1.5 \mathrm{mg} \mathrm{kg}^{-1}$ \\
\cline { 2 - 3 } & Cadmium & $1 \mathrm{mg} \mathrm{kg}^{-1}$ \\
\cline { 2 - 3 } & Mercury & $0.5 \mathrm{mg} \mathrm{kg}^{-1}$ \\
\hline \multirow{2}{*}{ Dioxins and PCBs } & Dioxins & $4 \mathrm{pg} \mathrm{g}^{-1}$ \\
& Dioxins + dl-PCBs & $8 \mathrm{pg} \mathrm{g}^{-1}$ \\
\hline PAHs & Benzo[a]pyrene & $10 \mathrm{mg} \mathrm{kg}^{-1}$ \\
\hline
\end{tabular}


Table 3 Levels of contamination in environment and in shellfish flesh sampled from the marketplace for three inorganic contaminants (Cd: cadmium; Pb: lead; Hg: mercury) regulated according to EC (2006c) and amended by EC (2008a). Arsenic (As), though not regulated, is included in the table, because it is also closely monitored

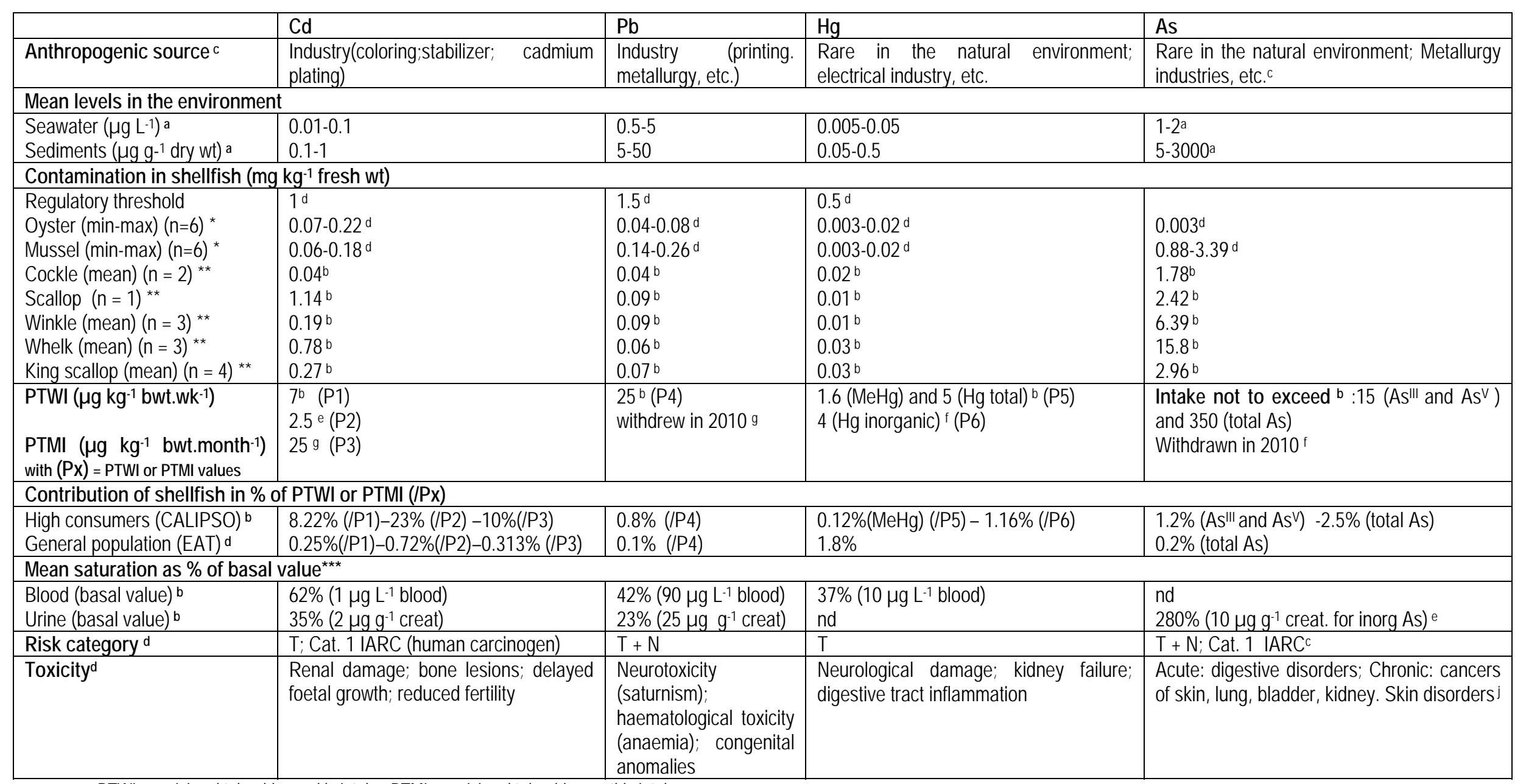

PTWI: provisional tolerable weekly intake; PTMI: provisional tolerable monthly intake

a. Merian et al. 2004; b. CALIPSO (Leblanc et al. 2006) c. INRS (2010) Toxicology data sheets d. EAT 2004 e. EFSA 2009 f. JEFCA 2010a. g. JEFCA 2010b

* Each sample consists in 5 sub-samples at most, weighted by main place of purchase main place of supply used by consumers on the Secodip panel. Analyses involved an amount of about $0.6 \mathrm{~g}$ per composite sample and replicate analyses were performed on each sample.

** Each sample of fresh product analysed consists in about $1000 \mathrm{~g}$ of product i.e., 5 sub-samples of $200 \mathrm{~g}$. The origin and distribution of the 5 sub-samples was determined according to place of purchase selected from data on frequency of purchase in the consumer survey, which were weighted by frequency of consumption and quantities consumed.

***basal value: value found for the 95th percentile of the general French population not occupationally exposed (EAT 2004)

n: number of samples. nd: not determined; $\mathrm{T}$ : toxic; $\mathrm{N}$ : dangerous for the environment 
Table 4 Levels of contamination in the environment and in shelfish sampled from the marketplace for unregulated inorganic contaminants

\begin{tabular}{|c|c|c|c|c|c|c|c|c|c|c|}
\hline & $\mathrm{Ni}$ & $\mathrm{Cr}$ & $\mathrm{V}$ & $\mathrm{Mn}$ & $\mathrm{Cu}$ & $\mathrm{Zn}$ & Co & Se & $\mathrm{Mg}$ & Mo \\
\hline $\begin{array}{l}\text { Anthropogenic } \\
\text { sources }\end{array}$ & $\begin{array}{l}\text { Industry } \\
\text { (production of } \\
\text { stainless steel, } \\
\text { catalysis, } \\
\text { etc.) }\end{array}$ & $\begin{array}{l}\text { Industry (anti- } \\
\text { corrosion, } \\
\text { catalysis, } \\
\text { pigments, etc. }{ }^{b}\end{array}$ & $\begin{array}{l}\text { Titanium industry, } \\
\text { ports, } \\
\text { petrochemicals }^{c}\end{array}$ & $\begin{array}{l}\text { Industry } \\
\text { (catalysis, } \\
\text { battery } \\
\text { manufacture, } \\
\text { etc.) }\end{array}$ & $\begin{array}{l}\text { Electrical } \\
\text { industry, } \\
\text { construction, } \\
\text { etc. }\end{array}$ & $\begin{array}{l}\text { Industry } \\
\text { (anti- } \\
\text { corrosion } \\
\text { coatings, } \\
\text { alloys, etc.) } \\
\end{array}$ & $\begin{array}{l}\text { Industry } \\
\text { (alloys, } \\
\text { pigments, } \\
\text { fertilisers, etc.) } \\
\text { b }\end{array}$ & $\begin{array}{l}\text { Industry } \\
\text { (electrical, } \\
\text { metallurgy, } \\
\text { etc.) }\end{array}$ & $\begin{array}{l}\text { Industry } \\
\text { (chemical, } \\
\text { alloys, etc.) b }\end{array}$ & $\begin{array}{l}\text { Industry (alloys, } \\
\text { catalysis, } \\
\text { pigments, etc.) }\end{array}$ \\
\hline \multicolumn{11}{|c|}{ Mean levels in the environment } \\
\hline Seawater $\left(\mu \mathrm{g} \mathrm{L}^{-1}\right)$ & $0.6^{\mathrm{a}}$ & $0.2^{\mathrm{a}}$ & $1.9^{\mathrm{a}}$ & $0.01^{\mathrm{a}}$ & $0.005-0.05^{a}$ & $0.5-5 \mathrm{a}$ & $0.002^{a}$ & $0.09^{a}$ & $1.310^{6 \mathrm{~h}}$ & $\mathrm{nd}^{\mathrm{h}}$ \\
\hline Sediments ( $\mu \mathrm{g} \mathrm{g}^{-1}$ dry wt) & $45^{a}$ & $60^{a}$ & $252^{\mathrm{a}}$ & $1.2^{\mathrm{a}}$ & $5-50^{a}$ & $50-500$ a & $0.045^{a}$ & $1.710^{-4 a}$ & $45^{\mathrm{h}}$ & $8.10^{-4 a}$ (b) \\
\hline \multicolumn{11}{|c|}{ Mean contamination of shellfish ( $\mathrm{mg} \mathrm{kg}^{-1}$ fresh wt) } \\
\hline $\begin{array}{l}\text { Oysters (min-max) }(n=6)^{*} \\
\text { Mussels (min-max) }(n=6) \text { * }\end{array}$ & $\begin{array}{l}0.03-0.17^{\dagger} \\
0.20-0.53^{\dagger}\end{array}$ & $\begin{array}{l}0.02-0.15^{\dagger} \\
0.07-0.25^{\dagger}\end{array}$ & $\begin{array}{l}6.3^{d} \\
7.3^{d}\end{array}$ & $\begin{array}{l}3.18-7.07^{\dagger} \\
1.32-3.68^{\dagger}\end{array}$ & $\begin{array}{l}6.90-30.1^{\dagger} \\
0.89-2.39^{\dagger}\end{array}$ & $\begin{array}{l}111-312^{\dagger} \\
8.23-26.7^{\dagger}\end{array}$ & $\begin{array}{l}0.01-0.05^{\dagger} \\
0.07-0.18^{\dagger}\end{array}$ & $\begin{array}{l}0.011^{\dagger} \\
0.011^{\dagger}\end{array}$ & $\begin{array}{l}590-957^{\dagger} \\
160-673^{\dagger}\end{array}$ & $\begin{array}{l}0.02-0.20^{f} \\
0.05-0.51^{f}\end{array}$ \\
\hline $\begin{array}{l}\text { Recommended nutritional } \\
\text { intake per day }\left(d^{-1}\right)\end{array}$ & & & & $2-3 \mathrm{mg} \mathrm{d}^{-1} \mathrm{~g}$ & $0.8-2 \mathrm{mg} \mathrm{d}^{-19}$ & $6-19 \mathrm{mg} \mathrm{d}^{-1 \mathrm{~g}}$ & $0.6 \mu \mathrm{g} \mathrm{d}^{-1 \mathrm{~g}}$ & $20-80 \mu \mathrm{g} \mathrm{d}^{-1 \mathrm{~g}}$ & $80-420 \mathrm{mg} \mathrm{d}^{-1 \mathrm{~g}}$ & $\begin{array}{l}30-50 \mu \mathrm{g} \mathrm{d}^{-1} \mathrm{~g} \\
\text { (a) }\end{array}$ \\
\hline Intake not to exceed & nd & nd & $100 \mu \mathrm{g} \mathrm{d}^{-1 \mathrm{~g}}$ & $4.2-10 \mathrm{mg} \mathrm{d}^{-19}$ & nd & $15-40 \mathrm{mg} \mathrm{d}^{-1 \mathrm{~g}}$ & $200 \mu \mathrm{g} \mathrm{d}^{-1 \mathrm{~g}}$ & $150 \mu \mathrm{g} \mathrm{d}^{-1 \mathrm{~g}}$ & $750 \mathrm{mg} \mathrm{d}^{-1 \mathrm{~g}}$ & $350 \mu \mathrm{g} \mathrm{d}^{-19}$ \\
\hline \multicolumn{11}{|c|}{ Intake from shellfish ingestion in adult men } \\
\hline & $0.76 \mu \mathrm{g} \mathrm{d}^{-1 \mathrm{f}}$ & $0.23 \mu \mathrm{g} \mathrm{d}^{-1 \mathrm{f}}$ & nd & $0.01 \mathrm{mg} \mathrm{d}^{-1 \mathrm{f}}$ & $0.02 \mathrm{mg} \mathrm{d}^{-1 \mathrm{f}}$ & $0.11 \mathrm{mg} \mathrm{d}^{-1 f}$ & $0.12 \mu \mathrm{g} \mathrm{d}^{-1 f}$ & $0.03 \mu \mathrm{g} \mathrm{d}^{-1 \mathrm{f}}$ & $1.2 \mathrm{mg} \mathrm{d}^{-1 f}$ & $0.33 \mu \mathrm{g} \mathrm{d}^{-1} f$ \\
\hline Risk category & $\begin{array}{l}\mathrm{Xn}+\mathrm{T} \\
\text { (monoxide) }{ }^{\mathrm{b}}\end{array}$ & $\begin{array}{l}\mathrm{T}+\mathrm{N} ; \mathrm{Cr}(\mathrm{VI}) \text { Cat. } \\
1 \text { IARC (human } \\
\text { carcinogen) } \mathrm{b}\end{array}$ & $\begin{array}{l}\text { Xn (divanadium } \\
\text { pentaoxide); } \\
\text { combustible } \\
\text { (vanadium trioxide) } \\
\text { e }\end{array}$ & $\begin{array}{ll}\mathrm{Xn} & (\mathrm{Mn} \\
{\text { dioxide })^{\mathrm{b}}}\end{array}$ & $\mathrm{Xn}^{\mathrm{b}}$ & $\begin{array}{l}\text { C (chloride); } \\
\text { Xi (sulphate); } \\
\text { T (chromate) } \\
+\mathrm{N}^{\mathrm{b}}\end{array}$ & $\begin{array}{ll}T+N & (C 0 \\
\text { sulphate); } & X n \\
\text { (cobalt) b } & \end{array}$ & $T+N^{b}$ & $\begin{array}{l}\mathrm{Xi} \\
\text { chloride })^{\mathrm{b}}\end{array}$ & $X i^{b}$ \\
\hline Toxicity & $\begin{array}{l}\text { Digestive } \\
\text { disorders; } \\
\text { probable } \\
\text { carcinogenic } \\
\text { effect }^{\mathrm{b}}\end{array}$ & $\begin{array}{l}\mathrm{Cr}(\mathrm{VI}) \text { : Digestive } \\
\text { disorders; kidney } \\
\text { failure }^{b}\end{array}$ & $\begin{array}{l}\text { Severe systemic } \\
\text { poisoning } \\
\text { symptoms and } \\
\text { death (divanadium } \\
\text { pentaoxide); } \\
\text { headaches, } \\
\text { vomiting } \\
\text { (vanadium trioxide) } \\
\mathrm{e}\end{array}$ & $\begin{array}{l}\text { Chronic: } \\
\text { nervous and } \\
\text { respiratory } \\
\text { disorders }{ }^{\mathrm{b}}\end{array}$ & $\begin{array}{l}\text { Chronic: } \\
\text { hepatitis; } \\
\text { neurological } \\
\text { disorders }^{b}\end{array}$ & $\begin{array}{l}\text { Digestive } \\
\text { disorders }^{b}\end{array}$ & $\begin{array}{l}\text { Irritative } \\
\text { respiratory } \\
\text { syndrome }{ }^{\text {b }}\end{array}$ & $\begin{array}{l}\text { Digestive } \\
\text { disorders; } \\
\text { neurological } \\
\text { signs b }\end{array}$ & $\begin{array}{l}\text { Muscular } \\
\text { tetany, } \\
\text { digestive } \\
\text { disorders }^{f}\end{array}$ & $\begin{array}{l}\text { Diarrhoea, } \\
\text { anaemia, } \\
\text { erythrocytic } \\
\text { immaturity, } \\
\text { uricemia } f\end{array}$ \\
\hline
\end{tabular}

a- Merian et al. 2004; b- INRS(2010) Toxicology data sheets; c- Saavedra et al. 2004; d- Roux et al. 2001; e- International chemical safety sheets 2010; f- EAT 2004; $g$ AFSSA 2008b; h- OSPAR 2008

* The shellfish contamination data were obtained from an individual composite sample of 5 sub-samples at most, weighted by main place of purchase used by consumers on the Secodip panel. Analyses involved an amount of about $0.6 \mathrm{~g}$ per composite sample and replicate analyses were performed on each sample.

nd: not determined; T: toxic; N: dangerous for environment; Xn: noxious; C: corrosive; Xi: irritant; (a) estimated adult requirement - no DRI value; (b) estimated concentration 
Table 5 Radionuclides in the environment and in shellfish sampled from the marketplace

\begin{tabular}{|c|c|}
\hline & Radionuclides ${ }^{99}$ Tc. ${ }^{129}$ I. ${ }^{226} \mathrm{Ra} .{ }^{210} \mathrm{Po} .{ }^{238} \mathrm{U} .{ }^{239} \mathrm{Pu} .{ }^{240} \mathrm{Pu} .{ }^{241} \mathrm{Am}$ \\
\hline Anthropogenic sources & Nuclear industry; fertilizer manufacture ${ }^{a} ;$ mining ${ }^{c}$ \\
\hline \multicolumn{2}{|l|}{ Mean levels in the environment } \\
\hline Seawater $\left(\mu \mathrm{g} \mathrm{L}^{-1}\right)$ & $\begin{array}{l}{ }^{137} \mathrm{Cs} 0.002-0.500 \mathrm{~Bq} \mathrm{~L}^{-1 \mathrm{a}} \\
{ }^{99} \mathrm{Tc} 0.350 \mathrm{~Bq} \mathrm{~L}-1 \mathrm{a} \\
\text { 210Po } 1-5 \mathrm{~Bq} \mathrm{~m}^{-3 \mathrm{c}}\end{array}$ \\
\hline Sediments ( $\left.\mu \mathrm{g} \mathrm{g}^{-1} \mathrm{dry} \mathrm{wt}\right)$ & 210Po 9 - $125 \mathrm{~Bq} \mathrm{~kg}^{-1 \mathrm{c}}$ \\
\hline \multicolumn{2}{|l|}{ Mean contamination of shellfish } \\
\hline $\begin{array}{l}\text { Mussels (min-max) } \\
\text { Cockles (min-max) } \\
\text { Molluscs (mean) }\end{array}$ & $\begin{array}{l}\text { 210Po } 150-600 \mathrm{~Bq} \mathrm{~kg}^{-1} \mathrm{dry} \mathrm{wt}^{\mathrm{c}} \\
\text { 210Po } 80-1200 \mathrm{~Bq} \mathrm{~kg}^{-1} \text { dry wt c } \\
\text { 210Po } 15 \mathrm{~Bq} \mathrm{kg-1} \text { dry wt b }^{\mathrm{c}}\end{array}$ \\
\hline Intake not to exceed & Men 2 mSv yr $^{-1}$ (probable maximum individual dose) ${ }^{a}$ \\
\hline $\begin{array}{l}\text { Maximum estimated intake from shellfish } \\
\text { ingestion, adult men }\end{array}$ & 210Po $160 \mu \mathrm{Sv} \mathrm{yr}^{-1} \mathrm{~b}$ \\
\hline Risk category & Radiological and chemical risk ${ }^{a}$ \\
\hline Toxicity & Irradiation, contamination, cancers \\
\hline
\end{tabular}

a- OSPAR 2007; b- Pradel et al. 2001; c- IRSN 2010 
Table 6 Levels of contamination in the environment and shellfish flesh sampled from the marketplace for regulated organic contaminants under Regulation (EC) №1881/2006 (EC 2006c)

\begin{tabular}{|c|c|c|c|c|}
\hline Contaminants & \multicolumn{2}{|l|}{ PCBs } & Dioxins and furanes & PAHs \\
\hline \multirow[t]{2}{*}{ Sources } & \multicolumn{2}{|c|}{$\begin{array}{l}\text { Industrial products: transformer and } \\
\text { condenser oils }{ }^{\text {b }} \\
\text { Paint plastifiers and plastics, } \\
\text { sealants }{ }^{\text {b }}\end{array}$} & $\begin{array}{l}\text { Incineration, metallurgy } \\
\text { processes }^{\mathrm{b}} \\
\text { Use of active chlorine for } \\
\text { bleaching paper pulp } \mathrm{p}^{\mathrm{b}} \\
\text { Internal combustion engines, } \\
\text { wildfire, wood burning e }\end{array}$ & $\begin{array}{l}\text { Constituents of crude oil, incineration and } \\
\text { incomplete burning of organic matter: wood, } \\
\text { coal, heating oil b. Oil production. Offshore } \\
\text { activities }^{b} \text {. Coal tar coatings, exhaust gases, } \\
{ }^{b} \text {. Wildfire, volcanic eruptions }{ }^{b}\end{array}$ \\
\hline & \multicolumn{4}{|c|}{$\begin{array}{l}\text { Current reservoirs: soil, sediments, rubbish dumps/landfills, old infrastructures }{ }^{b} \\
\text { Remobilisation of old sediments (dredging) } \\
\text { Rivers, atmosphere and ocean currents }^{\mathrm{b}} \text {, professional or recreational nautical activities }\end{array}$} \\
\hline \multicolumn{5}{|c|}{ Mean levels in the environment } \\
\hline $\begin{array}{l}\text { Seawater } \\
\left(n g L^{-1}\right)\end{array}$ & \multicolumn{2}{|l|}{$0.001^{b}$} & nd e & $\begin{array}{lr}\text { Benzo[a]pyrene } & 0.001-0.005^{\mathrm{b}} \\
\text { Fluoranthene } & 0.036-0.285^{\mathrm{b}} \\
\text { Benzo[b+k]fluoranthene } & 0.001-0.017^{\mathrm{b}} \\
\text { Pyrene } & 0.011-0.053^{\mathrm{b}} \\
\text { Total PAHs } & <0.0001-8500^{\mathrm{b}}\end{array}$ \\
\hline $\begin{array}{l}\text { Sediments } \\
(\mu \mathrm{g} \mathrm{kg}-1 \text { dry wt) }\end{array}$ & \multicolumn{2}{|c|}{$\begin{array}{l}\text { Congeneric PCBs } \\
(28 / 52 / 101 / 138 / 153 / 180) \\
<0.010-0.116^{b}\end{array}$} & $0.020^{\mathrm{e}}$ & $\begin{array}{lr}\text { Benzo[a]pyrene } & 0.2-112^{\mathrm{b}} \\
\text { Fluoranthene } & 0.72-160^{\mathrm{b}} \\
\text { Benzo[b+k]fluoranthene } & 1.1-434^{\mathrm{b}} \\
\text { Pyrene } & 0.6-128^{\mathrm{b}} \\
\text { Total estuarine PAHs } & 200-6000^{\mathrm{b}} \\
\end{array}$ \\
\hline \multicolumn{5}{|c|}{ Mean contamination of shellfish $\mathrm{pg} \mathrm{g}^{-1}$ fresh wt } \\
\hline $\begin{array}{l}\text { Oysters } \\
\text { Mussels } \\
\text { Scallops }\end{array}$ & $\begin{array}{l}\Sigma \mathrm{dl}-\mathrm{PCBS} \\
0.324^{\mathrm{a}} \\
0.334^{\mathrm{a}} \\
0.193^{\mathrm{a}}\end{array}$ & $\begin{array}{l}\text { PCBi } \\
2700^{\mathrm{a}} \\
3950^{\mathrm{a}} \\
4977^{\mathrm{a}}\end{array}$ & $\begin{array}{l}(\Sigma P C D D / F) \\
0.272^{a} \\
0.228^{a} \\
0.199^{a}\end{array}$ & $\begin{array}{l}\text { SPAH } \\
39.0-337^{\text {e }}\end{array}$ \\
\hline $\begin{array}{l}\text { Regulatory } \\
\text { thresholds }^{d}\end{array}$ & \multicolumn{2}{|c|}{$\Sigma(\mathrm{PCDD} / \mathrm{F}+\mathrm{dl}-\mathrm{PCB}) 8.0 \mathrm{pg} \mathrm{g}^{-1 \mathrm{~d}}$} & $\Sigma \mathrm{PCDD} / \mathrm{F} 4.0 \mathrm{pg} \mathrm{g}^{-1 \mathrm{~d}}$ & Benzo[a]pyrene $10.0 \mathrm{pg} \mathrm{g}^{-1 \mathrm{~d}}$ \\
\hline $\begin{array}{l}\text { TDI (ng kg-1 bwt d } \mathrm{d}^{-1} \text {.) } \\
\text { PTMI (pg kg-1 bwt } \\
\left.\text { month }{ }^{-1}\right)\end{array}$ & \multicolumn{2}{|c|}{$\begin{array}{l}\Sigma \text { PCB } 20 \text { (Aroclor eq.) }{ }^{c} \\
\Sigma \text { PCBi } 10 \mathrm{~g}\end{array}$} & $\begin{array}{l}0.001-0.004^{b} \\
\Sigma(\text { PCDD/F }+\Sigma \text { dl-PCBs }) 70^{f}\end{array}$ & \\
\hline $\begin{array}{l}\text { Daily intake from } \\
\text { food c }\end{array}$ & & & $\begin{array}{l}\Sigma(\text { PCDD/F+dl-PCB): } 1.8 \quad \mathrm{pg} \\
\text { WHO-TEQ kg-1 bwt d-1 }\end{array}$ & $\Sigma(6 \mathrm{PAH}): 1.4 \mathrm{ng}$ WHO-TEQ $/ \mathrm{kg}$ bwt/d \\
\hline $\begin{array}{l}\text { Toxicity } \\
\text { Ecotoxicity }\end{array}$ & \multicolumn{2}{|c|}{$\begin{array}{l}\text { Endocrine disruptor } \\
\text { neurotoxic, immunotoxic }{ }^{b}\end{array}$} & $\begin{array}{l}\text { Chloracne c } \\
\text { Immunodepressorc } \\
\text { Carcinogen }(2,3,7,8-T C D D)^{c}\end{array}$ & $\begin{array}{l}\text { Endocrine disruptor Benzo[a]pyrene: } \\
\text { carcinogen c. Less bioaccumulative and } \\
\text { biomagnifying than organochlorines. Slow } \\
\text { metabolisation in mussels / fish }{ }^{\text {b }}\end{array}$ \\
\hline Status & \multicolumn{2}{|c|}{$\begin{array}{l}\text { Main applications banned in France } \\
\text { (1987). Total end to use in } 2010^{\mathrm{b}}\end{array}$} & 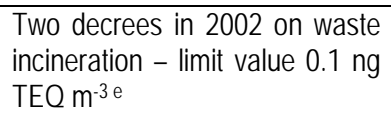 & $\begin{array}{l}\text { Decrees in } 1999 \text { limiting PAH emissions to } \\
0.1 \mathrm{mg} \mathrm{Nm}^{-3} \text { for boilers and engines } \mathrm{e}\end{array}$ \\
\hline
\end{tabular}

a. CALIPSO study (Leblanc et al. 2006); b. OSPAR 2008; c. AFSSA 2008b; d. Regulation (EC) 1881/2006 (EC 2006c); e. INERIS (2010)Toxicology data sheets; f. JECFA (2001); g. AFSSA (2005).

PCBi: sum of PCBs 28, 52, 101,138, 153, 180 (AFSSA 2005). 
Table 7 Levels of contamination in shellfish sampled from the marketplace for some unregulated organic contaminants

\begin{tabular}{|c|c|c|c|c|c|c|c|c|c|c|}
\hline & $\begin{array}{l}\text { TBT } \\
\text { Organostannic } \\
\text { compounds }\end{array}$ & HCB & Dieldrin & $\begin{array}{l}\text { DDT IDDE } \\
\text { IDDD } \\
\text { Total DDT }\end{array}$ & $\begin{array}{l}\text { Lindane } \\
\alpha-, \beta-, \gamma-\mathrm{HCH}\end{array}$ & $\begin{array}{l}\text { Toxaphe } \\
\text { ne }\end{array}$ & $\begin{array}{l}\text { Triazines } \\
\text { Atrazine, } \\
\text { simazine }\end{array}$ & Dichlorvos & $\begin{array}{l}\text { Brominated flame } \\
\text { retardants, , } \\
\text { Polybromodipheny } \\
\text { l ethers (PBDEs) } \\
\end{array}$ & Chlorinated paraffins \\
\hline Sources & \multicolumn{2}{|c|}{$\begin{array}{l}\text { Agricultural processes, antifouling agents, } \\
\text { fungicide agents, }{ }^{b} \quad \text { waste tips }{ }^{b} \text {.Current } \\
\text { reservoirs: soil, sediments, public waste tips } \\
\text { and old infrastructures, remobilisation of old } \\
\text { sediments (dredging) }{ }^{b} \\
\text { Direct inputs from rivers, atmosphere and } \\
\text { ocean currents }^{b} \text {, professional and } \\
\text { recreational nautical activities }{ }^{c}\end{array}$} & $\begin{array}{l}\text { Environmental stocks } \\
\mathrm{b}\end{array}$ & & $\begin{array}{l}\text { Agriculture, wood } \\
\text { treatment, veterinary } \\
\text { medicine, domestic use d } \\
\text { Control of crop pests, } \\
\text { cattle parasites and } \\
\text { commensal insects d }\end{array}$ & $\begin{array}{l}\text { Pesticide, } \\
\text { complex } \\
\text { mixtures } \\
\text { of } \\
\text { organochl } \\
\text { orines }^{b}\end{array}$ & Pesticide ${ }^{b}$ & $\begin{array}{l}\text { Used on salmon farms: parasiticide } \\
\text { against sea louse, insecticide - } \\
\text { acaricide b }\end{array}$ & $\begin{array}{l}\text { Automobile and } \\
\text { aeronautic padding, } \\
\text { textile and polymer } \\
\text { additives b, water } \\
\text { purification, } \\
\text { photography }\end{array}$ & $\begin{array}{l}\text { Plastifiers, } \\
\text { additives for } \\
\text { metal working } \\
\text { fluids, } \\
\text { flame } \\
\text { retardants, } \\
\text { leather industry b }\end{array}$ \\
\hline \multicolumn{11}{|c|}{ Mean levels in the environment } \\
\hline $\begin{array}{l}\text { Seawater }\left(\mathrm{ng} \mathrm{L}^{-1}\right) \\
\text { Sediments }\left(\mu \mathrm{g} \mathrm{kg}^{-1} \mathrm{dry}\right. \\
\mathrm{wt})\end{array}$ & $\begin{array}{l}0.6^{\mathrm{c}} \\
0.001^{\mathrm{c}} \\
\end{array}$ & $\begin{array}{l}\approx 1^{\mathrm{b}} \\
0.040-0.070^{\mathrm{b}}\end{array}$ & $\begin{array}{l}0.005-0.05^{b} \\
0.0005-0.005^{b}\end{array}$ & $\begin{array}{l}0.005-0.05^{b} \\
0.0005-0.005^{b}\end{array}$ & $0.0005-0.005^{b}$ & & $<2-42^{b}$ & & DeBDE $\quad 1-1700^{b}$ & $10^{\mathrm{b}}$ \\
\hline \multicolumn{11}{|c|}{ Ecotoxicological evaluation criteria* ${ }^{*}$} \\
\hline (mg/kg fresh wt) & & & & & & $10^{\mathrm{b}}$ & & & & \\
\hline \multicolumn{11}{|c|}{ Mean contamination of shellfish } \\
\hline $\begin{array}{l}\text { Mussel ( } \mu \mathrm{g} \mathrm{kg}^{-1} \mathrm{dry} \text { wt) } \\
\text { Mussel ( } \mu \mathrm{g} \mathrm{kg}^{-1} \text { fresh } \\
\mathrm{wt})\end{array}$ & $1.1^{\mathrm{g}}$ & & & DDE $5-50^{b}$ & $\approx 1 \mathrm{~b}$ & $\mathrm{Nd}$ & nd & nd & nd & nd \\
\hline $\begin{array}{l}\text { ADI }\left(\mathrm{ng} \mathrm{kg}^{-1} \text { bwt d }^{-1} \text {.) or }\right. \\
\text { other TRV }\end{array}$ & $\Sigma$ (organoSn) $250^{f}$ & $160^{b}$ & $\begin{array}{l}\text { aldrin }+ \text { dieldrin } \\
0.0001 \mathrm{mg} \mathrm{kg}^{-1} \mathrm{bwt}^{-1}\end{array}$ & & $0.005 \mathrm{mg} \mathrm{kg}^{-1} \mathrm{bwt} \mathrm{d}^{-1}$ & & $\begin{array}{l}\text { Atrazine }: 500 \\
\mathrm{ng} / \mathrm{kg}_{\mathrm{bwt}} / \mathrm{d} \\
\text { Simazine :520 } \\
\mathrm{ng} \mathrm{kg}^{-1} \mathrm{bwt}^{-1} \mathrm{~d}^{-1}\end{array}$ & $\begin{array}{l}80 \mathrm{ng} \mathrm{kg}^{-1} \mathrm{bwt} \mathrm{d}^{-1} \mathrm{e} \\
\mathrm{DL}_{50} \text { rat } 17-80 \mathrm{mg} \mathrm{kg}^{-1} \mathrm{bwt}^{\mathrm{d}} \\
\mathrm{DL}_{50} \text { mouse } 61-135 \mathrm{mg} \mathrm{kg}^{-1} \mathrm{bwt}^{\mathrm{d}} \\
\mathrm{DL}_{50} \text { rabbit } 10-12 \mathrm{mg} \mathrm{kg}^{-1} \mathrm{bwt}^{\mathrm{d}} \\
\mathrm{DL}_{50} \text { dog } 100 \mathrm{mg} \mathrm{kg}^{-1} \mathrm{bwt}^{\mathrm{d}}\end{array}$ & $\begin{array}{l}\text { No TRV exists a } \\
\text { LOAEL octaBDE: } \\
8 \mathrm{mg} \mathrm{kg}^{-1} \text { bwt d-1 } \\
\text { LOAEL pentaBDE }^{-1} \\
72 \mathrm{mg} \mathrm{kg}^{-1} \text { bwt d }^{-1}\end{array}$ & \\
\hline \multicolumn{11}{|c|}{ Daily intake from shellfish ingestion, adult men } \\
\hline$\left(\right.$ ng ind-1 $\left.\mathrm{d}^{-1}\right)$ & $\begin{array}{l}\text { Ratio }\left(\mathrm{ng} \mathrm{ind}^{-1} \mathrm{~d}^{-1}\right) /(\mathrm{ADI} \\
\mathrm{x} 60)=0.0034^{\mathrm{f}}\end{array}$ & & $\mathrm{Nd}$ & nd & nd & & & & $\begin{array}{l}\text { Fish and seafood: } \\
85^{\mathrm{b}} \\
150^{\mathrm{a}}\end{array}$ & \\
\hline Risk caregory & T. Na & & & & $\mathrm{R} 23 / 24 / 25 . \mathrm{R} 36 / 38^{\mathrm{d}}$ & & & R24/25d & & \\
\hline Toxicity/Ecotoxicity & $\begin{array}{lr}\text { TBT. } & \text { Endocrine } \\
\text { disrupter a } & \\
\text { TPT. toxic for } \\
\text { reproduction and } \\
\text { development a } \\
\text { DBT TBT. TPT: } \\
\text { immunotoxic a } \\
\end{array}$ & & & & Neurological disorders ${ }^{d}$ & & & $\begin{array}{ll}\text { Acetylcholinesterase } & \text { inhibitor } \\
\text { Mutagenic } & \\
\text { Carcinogenic } & \\
\text { Reprotoxic }^{d} & \end{array}$ & $\begin{array}{l}\text { Endocrine disrupter } \\
\text { Neurotoxic, } \\
\text { Potentially } \\
\text { carcinogenic }^{b}\end{array}$ & \\
\hline $\begin{array}{l}\text { Physico-chemical } \\
\text { properties and } \\
\text { phenomena } \\
\text { determining fate of } \\
\text { contaminants }\end{array}$ & & & & & $\begin{array}{l}\text { Poorly hydrosoluble. } \\
\text { Highly soluble in organic } \\
\text { solvents }{ }^{d}\end{array}$ & & & $\begin{array}{l}\text { Poorly hydrosoluble. Soluble in } \\
\text { organic solvents }{ }^{d}\end{array}$ & $\begin{array}{l}\text { Highly lipophilic. } \\
\text { Poorly hydrosoluble } \\
\text { Adsorbs strongly to } \\
\text { sediments }\end{array}$ & \\
\hline Status & $\begin{array}{l}\text { Total ban since } \\
01 / 01 / 08^{c}\end{array}$ & & Banned $\mathrm{b}$ & Banned $\mathrm{b}$ & & $\begin{array}{l}\text { Not used } \\
\text { in OSPAR } \\
\text { area }^{b}\end{array}$ & $\begin{array}{l}\text { Banned in } \\
\text { France }^{\mathrm{b}} \\
\text { Limited uses }^{\mathrm{b}}\end{array}$ & & & $\begin{array}{l}\text { End of use } \\
\text { for short-chain } \\
\text { paraffins scheduled } b\end{array}$ \\
\hline
\end{tabular}

TBT: tributyltin. TPT: triphenyltin, DBT: dibutyltin; HCB: hexachlorobenzene, T: toxic, N: dangerous for environment DDT, dichlorodiphenyltrichloroethane, DDE, dichlorodiphenyldichloroethylene, DDD, dichlorodiphenyldichloroethane, HCH, hexachlorocyclohexane, nd: n determined: R23/24/25: toxic by inhalation, skin contact, ingestion; R36/38: eye and skin irritant R24/25: toxic by inhalation, skin contact, ingestion

a. CALIPSO (Leblanc et al. 2006) ; b. OSPAR 2008; c. AFSSA 2006; d. INRS (2010)Toxicology data sheets; e. INERIS 2010; f. EFSA 2004b; g. Guérin et al. 2007 
Table 8 Bioconcentration factors for chemical contaminants in bivalve molluscs. Source: James et al. (2006)

\begin{tabular}{|l|l|}
\hline Substance & BCF in molluscs \\
\hline Anthracene & 260 (Macoma) \\
\hline Cadmium & 994 (invertebrates) \\
\hline C10-13 chloroalkanes & 40900 (mussels) \\
\hline Chlorfenvinphos & 255 (M. galloprovincialis) \\
\hline Diethylhexylphthalate & 2500 (mussels) \\
\hline Endosulfan & 600 (Mytilus) \\
\hline Fluoranthene & 10000 (Crassostrea) \\
\hline Hexachlorobenzene & 7000 (bivalves) \\
\hline Haxachlorobutadiene & 2000 (Mytilus) \\
\hline Hexachlorocyclohexanes & 161 (mussels) \\
(lindane) & 240 (Mytilus) \\
\hline Lead & 2279 (molluscs) \\
\hline Mercury* & 106 -107 \\
\hline Naphtalene & $27-38$ (mussels) \\
\hline Nickel & 270 (bivalves) \\
\hline Nonylphenols & 3000 (mussels) \\
\hline Octylphenols & 634 (calculated) \\
\hline Pentachlorobenzene & 2000 (bivalves) \\
\hline Pentachlorophenol & 390 (Mytilus) \\
\hline Benzo[a]pyrene & 12000 (Mytilus) \\
\hline TBTs & 11400 (Crassostrea) \\
\hline Trifluraline & 2360 (Helisoma) \\
\hline Aldrin & 43560 (calculated) \\
\hline Dieldrin & 7760 (calculated) \\
\hline Endrin & 5250 (calculated) \\
\hline Isodrin & 43650 (calculated) \\
\hline Total DDT & 45600 (molluscs) \\
\hline & \\
\hline
\end{tabular}

\footnotetext{
* bioamplification taken into account
} 
Table 9 Example half-lives for chemical contaminants that exist in bivalve molluscs

\begin{tabular}{|c|c|c|c|}
\hline Species & Chemical contaminant & Biological half-life (days) & Reference \\
\hline \multirow[t]{14}{*}{ Mytilus edulis } & TBT & $21-36$ & Yang et al. 2006 \\
\hline & TBT & 69 & Page et al. 1995 \\
\hline & DBT & 115 & Page et al. 1995 \\
\hline & Fluoranthene & 30 & Pruell et al. 1986 \\
\hline & Benzo[a]anthracene & 18 & Pruell et al. 1986 \\
\hline & Chrysene & 14 & Pruell et al. 1986 \\
\hline & Benzo[e]pyrene & 14 & Pruell et al. 1986 \\
\hline & Benzo[a]pyrene & 15 & Pruell et al. 1986 \\
\hline & Indenol[1.2.3-cd]pyrene & 16 & Pruell et al. 1986 \\
\hline & PCB 28 & 16 & Pruell et al. 1986 \\
\hline & PCB 101 & 28 & Pruell et al. 1986 \\
\hline & PCB 128 & 37 & Pruell et al. 1986 \\
\hline & PCB 153 & 46 & Pruell et al. 1986 \\
\hline & $\mathrm{Zn}$ & 76 & Bryan 1976 \\
\hline Mytulis galloprovincialis & $\mathrm{Hg}$ & 1000 & Bryan 1976 \\
\hline Mya arenaria & TBT & $71-94$ & Yang et al. 2006 \\
\hline Gafrarium tumidum & $\mathrm{Ni}$ & $35 \pm 7$ & Hédouin et al. 2007 \\
\hline Venerupis decussata & TBT & $17-38$ & Gomez-Ariza et al. 1999 \\
\hline \multirow[t]{7}{*}{ Crassostrea gigas } & $\mathrm{Cu}$ & $11.6-25.1$ & Han et al. 1993 \\
\hline & $\mathrm{Zn}$ & $16.7-30.1$ & Han et al. 1993 \\
\hline & $\mathrm{Cd}$ & 137 & Geffard et al. 2002 \\
\hline & $\mathrm{Cu}$ & 430 & Geffard et al. 2002 \\
\hline & $\mathrm{Hg}$ & 44 & Bryan 1976 \\
\hline & $\mathrm{Zn}$ & 335 & Geffard et al. 2002 \\
\hline & $\mathrm{Zn}$ & 255 & Bryan 1976 \\
\hline \multirow[t]{11}{*}{ Crassostrea virginica } & Fluoranthene & $26-32$ & Sericano et al. 1996 \\
\hline & Pyrene & $10-12$ & Sericano et al. 1996 \\
\hline & Benzo[a]anthracene & $13-15$ & Sericano et al. 1996 \\
\hline & Chrysene & $12-16$ & Sericano et al. 1996 \\
\hline & Benzo[e]pyrene & $12-16$ & Sericano et al. 1996 \\
\hline & Benzo[a]pyrene & $9-10$ & Sericano et al. 1996 \\
\hline & Indenol[1.2.3-cd]pyrene & $10-11$ & Sericano et al. 1996 \\
\hline & PCB 26 & 22 & Sericano et al. 1996 \\
\hline & PCB 118 & $73-299$ & Sericano et al. 1996 \\
\hline & PCB 149 & $130->365$ & Sericano et al. 1996 \\
\hline & PCB 153 & $51-102$ & Sericano et al. 1996 \\
\hline Ostrea edulis & $\mathrm{Zn}$ & 890 & Bryan 1976 \\
\hline \multirow[t]{3}{*}{ Crassostrea belcheri } & $\mathrm{Cd}$ & $5-16$ & Lim et al. 1998 \\
\hline & $\mathrm{Cu}$ & $5-9$ & Lim et al. 1998 \\
\hline & $\mathrm{Pb}$ & $4-14$ & Lim et al. 1998 \\
\hline \multirow[t]{3}{*}{ Crassostrea iredaleii } & $\mathrm{Cd}$ & 4 & Lim et al. 1998 \\
\hline & $\mathrm{Cu}$ & 6 & Lim et al. 1998 \\
\hline & $\mathrm{Pb}$ & 6 & Lim et al. 1998 \\
\hline Isognomon isognomon & $\mathrm{Ni}$ & Infinite & Hédouin et al. 2007 \\
\hline
\end{tabular}


Table 10 The RNO/ROCCH monitoring program for the various conventions and directives (Water Framework Directive (WFD), Oslo and Paris convention (OSPAR), Barcelona convention (MED POL), and for the French Directorate General for Food (DGAL), with regard to water, biota and sediment

RNO (1979-2007)

\begin{tabular}{|c|c|c|c|}
\hline \multicolumn{4}{|c|}{ Sampling frequency } \\
\hline $\begin{array}{l}\text { Conventions I } \\
\text { Directives }\end{array}$ & Water & Biota & Sediment \\
\hline OSPAR \& Barcelona & & $\begin{array}{l}\text { Annual, in November } \\
\text { (at all } 80 \text { RNO sites) }\end{array}$ & $\begin{array}{l}\text { Every } 10 \text { years (entire } \\
\text { French coast) }\end{array}$ \\
\hline DGAI & & $\begin{array}{l}\text { Annual, in February (at } \\
\text { all } 80 \text { RNO sites) }\end{array}$ & \\
\hline \multicolumn{4}{|c|}{ RNO contaminants $(1979-2007)$} \\
\hline Metals & \multicolumn{3}{|c|}{$\begin{array}{l}\text { Cadmium }(\mathrm{Cd}) \text {, copper }(\mathrm{Cu}) \text {, mercury }(\mathrm{Hg}) \text {, } \\
\text { silver }(\mathrm{Ag}) \text {, chrome }(\mathrm{Cr}) \text {, nickel }(\mathrm{Ni}) \text {, lead }(\mathrm{Pb}) \text {, vanadium }(\mathrm{V}) \text {, zinc }(\mathrm{Zn})\end{array}$} \\
\hline Organochlorines & \multicolumn{3}{|c|}{$\begin{array}{l}\text { DDT, DDD, DDE, } \\
\text { lindane }(\gamma-\mathrm{HCH}), \alpha-\mathrm{HCH}, \\
\text { polychlorobiphenyls: indicator PCBs }(28,52,101,138,153,180) \\
\text { and dioxin-like PCBs }(105,118,156)\end{array}$} \\
\hline $\begin{array}{l}\text { Polycyclic hydrocarbons } \\
\text { (PAHs) }\end{array}$ & \multicolumn{3}{|c|}{$\begin{array}{l}\text { Naphtalene, mono-, di-, tri- and tetra-methyl naphthalenes, acenaphtylene, } \\
\text { acenaphtene, fluorene, mono and di methyl fluorenes, phenantrene, } \\
\text { anthracene, mono, di and tri methyl phenanthrenes/anthracenes, } \\
\text { fluoranthene, pyrene, mono and di methyl pyrenes/fluoranthenes, } \\
\text { benzo[a]anthracene, triphenylene, chrysene, mono and di methyl chrysene, } \\
\text { benzofluoranthenes, mono methyl benzofluoranthenes, benzo[e]pyrene, } \\
\text { benzo[a]pyrene, perylene, dibenzo[a, } h] \text { anthracene, benzo[g,h,]perylene, } \\
\text { indeno[1,2,3-cd]pyrene, sulphurated heterocycles: dibenzothiophene, } \\
\text { mono, di and tri methyl dibenzothiophene, benzonaphtothiophenes, } \\
\text { monomethyl benzonaphtothiophenes }\end{array}$} \\
\hline
\end{tabular}

ROCCH (since 2008)

\begin{tabular}{|c|c|c|c|}
\hline \multicolumn{4}{|c|}{ Sampling frequency } \\
\hline $\begin{array}{c}\text { Conventions I } \\
\text { directives }\end{array}$ & Water & Biota & Sediment \\
\hline WFD & $\begin{array}{l}\text { Monthly for } 12 \text { months } \\
\text { every } 6 \text { years (at all } \\
\text { WFD sites) }\end{array}$ & $\begin{array}{l}\text { Annual in November } \\
\text { (at } 25 \% \text { of WFD sites) }\end{array}$ & $\begin{array}{l}\text { Every } 6 \text { years (at } 25 \% \\
\text { of WFD sites) }\end{array}$ \\
\hline OSPAR \& Barcelona & & $\begin{array}{l}\text { Annual in November } \\
\text { (at } 50 \% \text { of WFD sites) }\end{array}$ & $\begin{array}{l}\text { Every } 6 \text { years (at } 50 \% \\
\text { of WFD sites) }\end{array}$ \\
\hline DGAL & & $\begin{array}{l}\text { Annual in February, } \\
\mathrm{Cd}, \mathrm{Hg}, \mathrm{Pb} \text { (on } 131 \\
\text { sites) }\end{array}$ & \\
\hline \multicolumn{4}{|c|}{ ROCCH contaminants (WFD + OSPAR + DGAL) } \\
\hline Metals & \multicolumn{3}{|c|}{ Cadmium (Cd), mercury $(\mathrm{Hg})$, nickel $(\mathrm{Ni})$, lead $(\mathrm{Pb})$} \\
\hline Organic contaminants & \multicolumn{3}{|c|}{$\begin{array}{l}\text { Polychlorobiphenyls: indicator PCBs }(28,52,101,138,153,180) \\
\text { and dioxin-like PCBs }(105,118,156) \\
\text { Alachlore, anthracene, atrazine, benzene, pentabromodiphenylether, octa- } \\
\text { bromodiphenylether, deca-bromodiphenylether, C10-13 chloroalkanes, } \\
\text { chlorfenvinphos, chlorpyrifos, } 1,2 \text { dichloroethane, dichloromethane, di (2- } \\
\text { ethylhexyl)phtalate (DEHP), diuron, endosulfan (family), fluoranthene, } \\
\text { hexachlorobenzene, hexachlorobutadiene, hexachlorocyclohexane (alpha, } \\
\text { beta, delta), lindane, isoproturon, naphthalene, nonylphenols, 4-n- } \\
\text { nonylphenol, para-nonylphenols, octylphenol, para-ter-octylphenol, } \\
\text { pentachlorobenzene, pentachlorophenol, benzo[a]pyrene, } \\
\text { benzo[b]fluoranthene, benzo[g, } h,] \text {, }] \text { perylene, benzo[k]fluoranthene, } \\
\text { indeno[1,2,3-cd]pyrene, simazine, tributyltin, trichlorobenzene, 1,2,4- } \\
\text { trichlorobenzene, trichloromethane (chloroform), trifluralin, aldrin, carbon } \\
\text { tetrachloride, total DDT, para-para DDT, dieldrin, endrin, perchloroethylene } \\
\text { (tetrachloroethylene), trichloroethylene, isodrin, }\end{array}$} \\
\hline
\end{tabular}


Table 11 Concentrations of certain contaminants (fresh wt)* observed in oysters from Arcachon Bay (RNO survey 02/2000-11/2005), and in mussels (Devier et al. 2005)

\begin{tabular}{|c|c|c|}
\hline Contaminant & Oysters (mean \pm s.d.) (n) & $\begin{array}{l}\text { Mussels (min-max of means } \\
\text { depending on site) }(n)\end{array}$ \\
\hline \multicolumn{3}{|l|}{ Inorganic (mg kg ${ }^{-1}$ fresh wt) } \\
\hline Cadmium & $0.23 \pm 0.09$ & $0.14-0.18(84)$ \\
\hline Lead & $0.18 \pm 0.04(54)$ & $0.25-0.31(84)$ \\
\hline Mercury & $0.03 \pm 0.011(54)$ & nd \\
\hline Arsenic & $\mathrm{Nd}$ & $2.5-2.9(84)$ \\
\hline Nickel & $0.21 \pm 0.04(18)$ & $0.20-0.25(84)$ \\
\hline Chrome & $0.17 \pm 0.08(42)$ & $0.23-0.34(84)$ \\
\hline Vanadium & $0.33 \pm 0.12(18)$ & nd \\
\hline Copper & $24.51 \pm 9.62(54)$ & $1.1-4.1(84)$ \\
\hline Zinc & $372 \pm 112(54)$ & $28-42(84)$ \\
\hline Selenium & $\mathrm{Nd}$ & $1.6-2.2(84)$ \\
\hline Silver & $0.79 \pm 0.33(18)$ & nd \\
\hline \multicolumn{3}{|l|}{ Organic (pg g ${ }^{-1}$ fresh wt) } \\
\hline Organostannics (amount in Sn) & $\mathrm{Nd}$ & $7.2-39410^{3}$ \\
\hline PCBs (sum of 6 congeners) & $5.210^{3} \pm 3.610^{3}(21)$ & $5.4-7.010^{3}$ \\
\hline PAHs (amount EPA PAHs ) & $4010^{3} \pm 1110^{3}(15)$ & $13.3-26210^{3}$ \\
\hline DDT / DDE / DDD (sum of the 3) & $2.310^{3} \pm 1.310^{3}(24)$ & nd \\
\hline Lindane $(\alpha-, \gamma-\mathrm{HCH})$ (sum of the 2) & $0.2310^{3} \pm 0.1010^{3}(24)$ & nd \\
\hline
\end{tabular}

* fresh weight obtained by multiplying dry weight value by 0.18 ; nd: not determined

n:number of samples. nd: not determined.

Table 12 Concentrations of certain contaminants ( $\mathrm{mg} \mathrm{kg}^{-1}$ fresh wt) observed in mussels from the Bay of Seine (RNO survey from 2003 to 2007)

\begin{tabular}{lcc}
\hline Contaminant & Mean \pm s.d. & Sample size \\
\hline Cadmium & $0.23 \pm 0.09$ & 48 \\
Lead & $0.49 \pm 0.26$ & 48 \\
Mercury & $0.04 \pm 0.02$ & 48 \\
Benzo[a]pyrène & $3.01 \pm 4.1010^{-3}$ & 24 \\
\hline
\end{tabular}


Table 13 Summary of cadmium non-compliances in reports from DGAL monitoring programs (20022005)

\begin{tabular}{|c|c|c|c|c|}
\hline Scallops & $\begin{array}{l}\text { Year of DGAL } \\
\text { monitoring program }\end{array}$ & Fishing area & $\begin{array}{l}\text { Cadmium test result } \\
\text { (mg kg-1 fresh wt) }\end{array}$ & $\begin{array}{l}\text { Cadmium confirmation } \\
\text { result (mg kg-1 fresh wt) } \\
\text { (AFSSA/LERQAP) }\end{array}$ \\
\hline \multirow[t]{8}{*}{ Chlamys varia } & \multirow{8}{*}{$\begin{array}{l}2005 \\
\text { Total no. of scallop } \\
\text { samples = } 14\end{array}$} & Pertuis Breton & 1.18 & $* 1.26 \pm 0.18$ \\
\hline & & Pertuis Breton & 1.65 & $1.64 \pm 0.23$ \\
\hline & & Pertuis Breton & 1.12 & $1.05 \pm 0.21$ \\
\hline & & Pertuis Breton & 1.12 & $1.07 \pm 0.21$ \\
\hline & & Pertuis Breton & 1.40 & $1.07 \pm 0.21$ \\
\hline & & Quiberon Bay & 1.54 & $1.62 \pm 0.23$ \\
\hline & & Quiberon Bay & 1.5 & $1.56 \pm 0.22$ \\
\hline & & Quiberon Bay & 1.06 & $1.13 \pm 0.16$ \\
\hline $\begin{array}{l}\text { Aequipecten } \\
\text { opercularis }\end{array}$ & $\begin{array}{l}2004 \\
\text { Total no. of scallop } \\
\text { samples = } 3\end{array}$ & $\begin{array}{l}\text { Western } \\
\text { Channel }\end{array}$ & 1.13 & 1.33 \\
\hline \multirow[t]{2}{*}{ Chlamys varia } & \multirow{2}{*}{$\begin{array}{l}2002 \\
\text { Total no. of scallop } \\
\text { samples = } 9\end{array}$} & \multirow[t]{2}{*}{ Not specified } & 1.5 & 1.7 \\
\hline & & & 1.6 & 1.7 \\
\hline
\end{tabular}

*Bold type: samples confirmed as non-compliant with Regulations (EC) 1881/2006 (EC 2006c)

Table 14 Daily human consumption ( $\mathrm{g} \mathrm{d}^{-1}$ of product consumed) according to the 2007 INCA 2 survey (INCA 2 2009)

\begin{tabular}{|c|c|c|c|c|c|c|c|c|}
\hline & \multicolumn{4}{|c|}{ Adults (normal estimators) ( $\mathrm{N}=1918$; aged 18 and older) } & \multicolumn{4}{|c|}{ Children ( $N=1455$; aged 3-17) } \\
\hline & $\begin{array}{l}\% \text { of } \\
\text { Consumers }\end{array}$ & Mean & $\begin{array}{l}\text { Standard } \\
\text { deviation }\end{array}$ & Median & $\begin{array}{l}\% \text { of } \\
\text { Consumers }\end{array}$ & Mean & $\begin{array}{l}\text { Standard } \\
\text { deviation }\end{array}$ & Median \\
\hline Meat & 92.0 & 49.7 & 37.5 & 42.4 & 91.5 & 38.1 & 28.8 & 32.9 \\
\hline Fish & 79.3 & 26.5 & 24.7 & 21.2 & 78.7 & 18.3 & 17.6 & 14.3 \\
\hline $\begin{array}{l}\text { Molluscs and } \\
\text { crustaceans }\end{array}$ & 33.5 & 4.5 & 9.3 & 0 & 17.9 & 1.4 & 5.1 & 0 \\
\hline
\end{tabular}


Table 15 Detail of mollusc consumption by "high consumers" of seafood in the CALIPSO survey (Leblanc et al. 2006). Data given in $g$ week $^{-1}$ of fresh flesh

\begin{tabular}{|c|c|c|c|c|}
\hline Molluscs & Mean (g week ${ }^{-1}$ ) & P5 & P50 & P95 \\
\hline Bivalves & 119.7 & 7.5 & 79.8 & 350.3 \\
\hline Clam & 0.2 & 0 & 0 & 0 \\
\hline Cockle & 3.1 & 0 & 0 & 15.0 \\
\hline King scallop & 39.3 & 0 & 25.0 & 156.3 \\
\hline Razor clam & 0.4 & 0 & 0 & 0 \\
\hline Oyster & 34.4 & 0 & 18.0 & 144.0 \\
\hline Mussel & 22.5 & 0 & 17.5 & 70.0 \\
\hline Palourde clam & 2.8 & 0 & 0 & 12.3 \\
\hline Other scallops & 14.7 & 0 & 0 & 56.3 \\
\hline Warty venus & 1.5 & 0 & 0 & 7.5 \\
\hline Wedge-shell, olive & 0.3 & 0 & 0 & 0 \\
\hline Queen scallop & 0.5 & 0 & 0 & 0 \\
\hline Gastropods & 21.2 & 0 & 3.8 & 87.5 \\
\hline Winkle & 4.2 & 0 & 0 & 25.0 \\
\hline Whelk & 15.4 & 0 & 0 & 75.0 \\
\hline Abalone & 0.6 & 0 & 0 & 0 \\
\hline Limpet & 1.0 & 0 & 0 & 0 \\
\hline Echinoderms & 11.6 & 0 & 0 & 52.5 \\
\hline Sea urchin & 11.6 & 0 & 0 & 52.5 \\
\hline Tunicates & 1.0 & 0 & 0 & 0 \\
\hline Sea-squirt & 1.0 & 0 & 0 & 0 \\
\hline All & 153.5 & 10.0 & 106.1 & 413.5 \\
\hline
\end{tabular}

